\title{
Review of Soil Salinity and Sodicity Challenges to Crop Production in the Lowland Irrigated Areas of Ethiopia and Its Management Strategies
}

\author{
Ashenafi Worku Daba ${ }^{1, *,+(\mathbb{D})}$ and Asad Sarwar Qureshi ${ }^{2}(\mathbb{D}$ \\ 1 Ethiopian Institute of Agricultural Research (EIAR), Addis Ababa P.O. Box 2003, Ethiopia \\ 2 International Center for Bio-Saline Agriculture (ICBA), Dubai P.O. Box 14660, United Arab Emirates; \\ a.qureshi@biosaline.org.ae \\ * Correspondence: ashuw21@gmail.com; Tel.: +251-920-414176 \\ + Currently located at the Hawassa University, Shashemene P.O. Box 128, Ethiopia.
}

Citation: Daba, A.W.; Qureshi, A.S Review of Soil Salinity and Sodicity Challenges to Crop Production in the Lowland Irrigated Areas of Ethiopia and Its Management Strategies. Land 2021, 10, 1377. https://doi.org/ 10.3390/land10121377

Academic Editor: Amrakh

I. Mamedov

Received: 8 October 2021

Accepted: 6 December 2021

Published: 13 December 2021

Publisher's Note: MDPI stays neutral with regard to jurisdictional claims in published maps and institutional affiliations.

Copyright: (c) 2021 by the authors. Licensee MDPI, Basel, Switzerland. This article is an open access article distributed under the terms and conditions of the Creative Commons Attribution (CC BY) license (https:// creativecommons.org/licenses/by/ $4.0 /)$.

\begin{abstract}
Ethiopia's irrigated agriculture productivity has been threatened by severe salinity and sodicity problems which have resulted in significantly lower yields, food insecurity, and environmental degradation. The destructive effects of poor irrigation water management with the absence of drainage and anticipated future climate changes can accelerate the formation of salt-affected soil, potentially expanding the problem to currently unaffected regions. This paper synthesizes the available information on the causes, extent, and effects of salt-affected soils on soil and crop production and suggest chemical, biological, and physical reclamation and management approaches for tackling salinity and sodicity problems. The mitigation approaches (e.g., the addition of amendments, plantation of salt-tolerant crops, appropriate irrigation and drainage management, phytoremediation, and bioremediation) have successfully tackled soil salinity and sodicity problems in many parts of the world. These approaches have further improved the socioeconomic conditions of farming communities in salt-affected areas. The paper also discusses the effectiveness of these mitigation strategies under Ethiopian conditions. The policy interventions for reclamation of soil salinity and sodicity that indicates future research attention to restoring agricultural sustainability are also foci of this paper.
\end{abstract}

Keywords: salt-affected soil; soil amendment; drainage management; salt tolerant crop; livelihood sustainability

\section{Introduction}

Globally, salt-affected soils are a severe problem in lowland irrigated areas because of inappropriate irrigation practices and poor water quality. Globally, about $20 \%$ of the irrigated lands are affected by salinity and sodicity problems [1]. In addition, the world is losing at least 10 ha of arable land every minute [2]; from this, 3 ha are lost due to salinity and sodicity problems, especially in lowland irrigated regions of the world. Accumulation of soluble salts is the single most important factor in the formation of salt-affected soils in the arid and semi-arid areas where evaporation exceeds precipitation. The sources of salts include saline parent materials particularly weathering of rocks and primary minerals, fossil salts of former marine and lacustrine deposits, atmospheric deposition, collection of saline sediments in catchment areas, irrigation waters and/or fertilization [3]. During the weathering process, both physical and chemical, salts are released from rocks and minerals of the Earth's crust. In arid regions, salts are brought in by streams draining into the basins [1]. In sub-humid regions, dissolved sodium accumulates as exchangeable sodium, due to vertical or horizontal leaching. Salt-affected soils often occur on irrigated lands, especially in arid and semi-arid regions, where annual rainfall is insufficient to meet the evaporation needs of plants and leaching of salts [4]. In humid areas, soluble 
salts are carried down through the soil profile by percolating rainwater and ultimately are transported to sea.

The soluble salts that occur in salt-affected soils consist mostly of various proportions of $\mathrm{Na}^{+}, \mathrm{Ca}^{2+}, \mathrm{Mg}^{2+}, \mathrm{Cl}^{-}, \mathrm{SO}_{4}{ }^{2-}, \mathrm{HCO}_{3}{ }^{-}$and occasionally $\mathrm{K}^{+}, \mathrm{CO}_{3}{ }^{2-}$ and $\mathrm{NO}_{3}{ }^{-}$ions with minor quantities of $\mathrm{B}, \mathrm{F}$ and $\mathrm{Li}$ that are seldom of major importance because of their toxicity to plants [5]. These ionic constituents of salt-affected soils are released and made soluble from rocks and weatherable minerals during the processes of geochemical and pedochemical weathering. Four main sources of the constituents of soil salinity and sodicity $\left\{\mathrm{Na}^{+}, \mathrm{Ca}^{2+}, \mathrm{Mg}^{2+}, \mathrm{K}^{+}\right.$(common metals) and $\mathrm{SO}_{4}{ }^{2-}, \mathrm{Cl}^{-}, \mathrm{HCO}_{3}{ }^{-}, \mathrm{NO}_{3}{ }^{-}$(common ligands) $\}$ are (a) mineral weathering (Na rich feldspars), (b) precipitation or rainfall, (c) fossil salts (marine or lacustrine deposits) and (d) collection of saline sediments in catchment areas $[1,5]$. Salts may also be introduced in irrigation water, or because of fertilization.

Depending on the climatic conditions, the accumulated soluble salts may adequately be leached out of the profile in humid environments. However, in arid environments where ET exceeds rainfall during some periods of the year, removal of salts through rainfall is very low compared with the rate of their removal by irrigation water [4]. Therefore, the processes of secondary salinization in arid and semi-arid climatic regions are the consequences of quite diverse and interacting factors of surface and ground waters, soil physical properties, climate, relief and geomorphology, biological activities, and human interference [2].

Several researchers have reported the widespread occurrence of soil and water salinity and sodicity in the lowland irrigated areas of Ethiopia [3-5]. Ethiopia's total land area affected by salinity is $11,033,000$ ha, and it is ranked first in Africa [6]. Following Ethiopia are Chad, Egypt, and Nigeria, having a total area of 8,267,000, 7,360,000, and 6,502,000 ha of salt-affected lands, respectively [6].

Most of these areas are present in the rift valley, the Denakil Plains, Wabi Shebelle River Basin, and lowlands irrigated areas of the country [3]. The problem is aggravated due to inappropriate irrigation practices and lack of drainage schemes that resulted in rising groundwater levels $\left(\mathrm{EC}=0.9-13.4 \mathrm{dSm}^{-1}\right.$ ) closer to the soil surface, making the farm areas susceptible to secondary salinization. Due to poor irrigation practices and high evapotranspiration rates, about $33 \%$ of the total area of the Amibara irrigation scheme became salt-affected $\left(\mathrm{ECe}=4.03-65.71 \mathrm{dSm}^{-1}\right)$ within five to eight years [7]. Three leading causes for the development of salt-affected soils include primary or naturally induced salinity, secondary or human-induced, and their combination that is especially pronounced under ongoing climate change in water-scarce regions [3]. Soil salinity and sodicity reduce plant growth and affect soil properties by limiting water availability to plants; specific ions toxicity; imbalance plant nutrition; alteration of soil physical properties and effect composition and activity of beneficial soil microorganisms [3,8].

Salinity and sodicity is abiotic stress that hinders the growth of crops by limiting water and mineral take-ups, affecting human and animal health and the whole ecosystem $[9,10]$. Salt affected soils have incredible environmental, agricultural, ecological, and social impacts through reducing crop production and soil quality, resulting in unstable livelihood security, low economic returns, and poor quality of life [11]. Soil salinization has social consequences, including reduced agricultural product, low income, change of livelihood options, and related social constraints. This situation requires government support to reclaim saltaffected areas to avoid crop production and financial losses [12]. Farmers in salt-affected regions of the middle and lower awash basin are mostly resource-limited and require financial and technical support to sustain their livelihood efforts [5].

The problems of soil salinity and sodicity can be tackled by adopting different technologies, such as increasing irrigation rate by leaching fraction, gypsum amendment for the sodic soils, introducing salt-tolerant crops for highly saline areas, managing poor quality irrigation water, and restoring salty lands using forestry species [13]. The overall objective of this paper is to assess the challenges of soil salinity and sodicity on crop production and recommend the best management options that are cost-effective. 


\section{Cause and Type of Salt-Affected Soils}

The common causes of soil salinity and sodicity are geological, hydrological, and pedological processes. Primary soil salinization is governed by; (i) seawater intrusion via upstream river flows and through underground porous geomorphological shoreline structures [14]; (ii) wind deposition of salts from saline and/or sodic water resources onto adjacent lands [15]; and (iii) in situ dissolution and substantial surface deposit of endogenous (parent) minerals [16].

The process of salinization in the Awash River Basin [17-20] of Ethiopia is somewhat more diverse and complicated. This is mainly because of the presence of residual or fossil salts of former alluvial, colluvial, lacustrine and/or marine deposits of the weathered products of the salt and sodium-rich primary minerals of igneous rocks originating from the volcanic regions of the central highlands and the rift valley system of the country [20]. The mineralized surface water and groundwater, inefficient irrigation practices, inadequate drainage systems, lowland areas, and arid climate or inadequate annual rainfall to leach down accumulated salts from the plant root zone are other significant causes (Figure 1). The criteria used to classify salt-affected soils is given in Table 1.

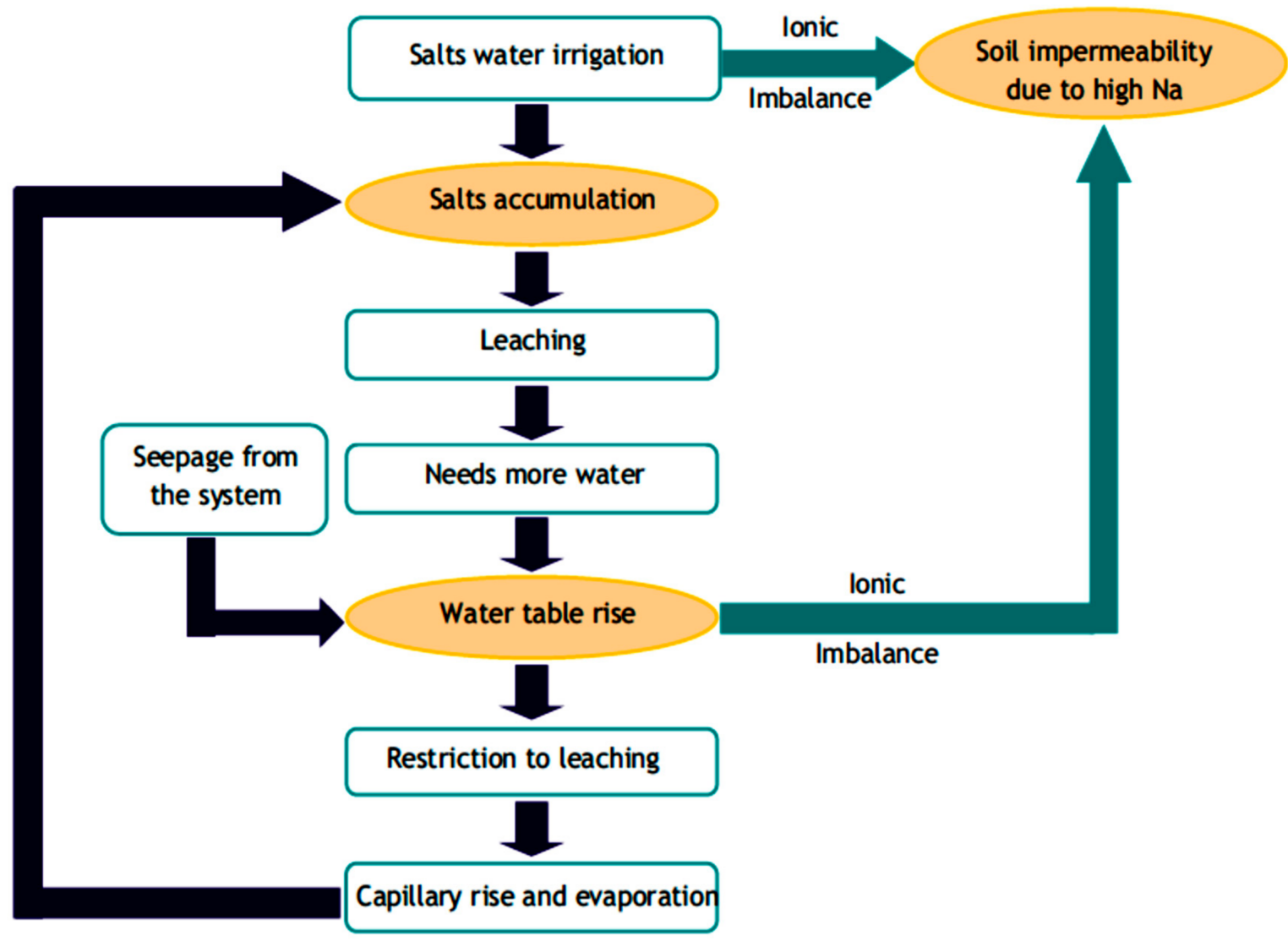

Figure 1. A theoretical secondary salinization cycle [21]. 
Table 1. Summary of classification of salt affected soils based on their chemical properties [22].

\begin{tabular}{cccc}
\hline $\begin{array}{c}\text { Salt Affected Soil } \\
\text { Type }\end{array}$ & $\begin{array}{c}\text { Electrical } \\
\text { Conductivity of } \\
\text { Saturation Extracts } \\
\text { (ECe) at } \mathbf{2 5}^{\circ} \mathbf{C} \\
\mathbf{d S S m}^{-\mathbf{1})}\end{array}$ & $\begin{array}{c}\text { Saturation (\%) of } \\
\text { Cation Exchange } \\
\text { Capacity with Na } \\
\text { (ESP) }\end{array}$ & $\begin{array}{c}\text { Reaction } \\
\text { (pH Value) }\end{array}$ \\
\hline Saline soil & $>4$ & $<15$ & $<8.5$ \\
Saline sodic soil & $>4$ & $>15$ & $<8.5$ \\
Sodic (alkali) soil & $<4$ & $>15$ & $8.5-10$ \\
Non-saline non-sodic & $<4$ & $<15$ & About neutral \\
\hline
\end{tabular}

Soils having soluble salts in solution and/or $\mathrm{Na}^{+}$ions on exchange sites exceeding certain limits can adversely affect soil-plant health [23,24]. Salt-affected soils are classified into three categories: saline, saline-sodic, and sodic, mainly based on total soluble salts (EC) and sodium hazards (sodium adsorption ratio (SAR) or exchangeable sodium percentage (ESP) of a soil system. Overall rehabilitation and management of salt-affected soils depend on the classification of salt types [25], especially saline-sodic and sodic soils that need investment [26]. Generally, understanding the kind of salts is very dominant for the management and rehabilitation of salt-affected soils.

\section{Extent and Distribution of Saline and Sodic Soils in Ethiopia}

Ethiopia stands 9th in terms of total land and 7th in percent of the total salt-affected area among the various countries in the world. Despite the widespread existence of saltaffected soils, no accurate data and information is available on their extent, distribution, exact geographical location, sources, causes, and properties. However, many of these soils are concentrated in the plain lands of the lowland regions (Afar, Oromia and Amhara), Rift Valley System, the Denakil Plains, Wabi Shebelle River Basin, and various other lowlands and valley bottoms throughout the country [3,5]. Recently, salt-affected irrigated farmlands of four regions (Afar, Oromia, Amhara, and Tigray) of Ethiopia have been mapped using remote-sensing and soil data and the results are presented in Figure 2 and Table 2 [5].

The total land covered by salt-affected soils in the former Hararghe Administrative Region alone is estimated to be $1,159,300 \mathrm{ha}$, which is about $12.9 \%$ of the arable land area in the Region [3]. In Amibara irrigated area (14,787.58 ha), 70\% of the soils are Fluvisols and the rest $30 \%$ are Vertisols, with a coverage of about $33.20 \%$ and $8.76 \%$ of the total salt affected area, respectively [27]. Furthermore, reports have also indicated that $39 \%$ of the Abaya State Farm was salt affected [28]. The baseline survey results revealed that there are 119 and 10,000 ha of salinity and sodicity soils in the Tigray and Southern Nations, Nationalities, and the People Regional States, respectively [3].

Table 2. Percentage of area coverages by salinity soils classes of Afar, Amhara, Oromia, and Tigray regions of Ethiopia [5].

\begin{tabular}{ccccccccc}
\hline \multirow{2}{*}{$\begin{array}{c}\text { Soil Salinity Levels } \\
\left(\mathbf{d S m}^{-1} \mathbf{)}\right.\end{array}$} & \multicolumn{2}{c}{ Afar } & \multicolumn{2}{c}{ Oromia } & \multicolumn{2}{c}{ Amhara } & \multicolumn{2}{c}{ Tigray } \\
\cline { 2 - 9 } & $\mathbf{K m}^{\mathbf{2}}$ & $\mathbf{\%}$ & $\mathbf{K m}^{\mathbf{2}}$ & $\mathbf{\%}$ & $\mathbf{K m}^{\mathbf{2}}$ & $\mathbf{\%}$ & $\mathbf{K m}^{\mathbf{2}}$ & $\mathbf{\%}$ \\
\hline Non-saline (<2) & 40,787 & 42 & $287,768.25$ & 88.70 & 137,428 & 88 & 48,067 & 97.29 \\
Low saline (2-5) & 26,961 & 28 & $17,292.05$ & 5.33 & 4903 & 3 & 0 & 0 \\
Medium saline (5-10) & 9798 & 10 & $17,152.54$ & 5.29 & 11,892 & 8 & 1339 & 2.71 \\
High saline (10-15) & 5618 & 5 & 1576.72 & 0.49 & 1230 & 0.8 & 0 & 0 \\
Extremely saline (>15) & 14,085 & 15 & 713.74 & 0.22 & 202 & 0.2 & 0 & 0 \\
\hline Total area & 97,204 & 100 & $324,428.69$ & 100 & 155,648 & 100 & 49,604 & 100 \\
\hline
\end{tabular}




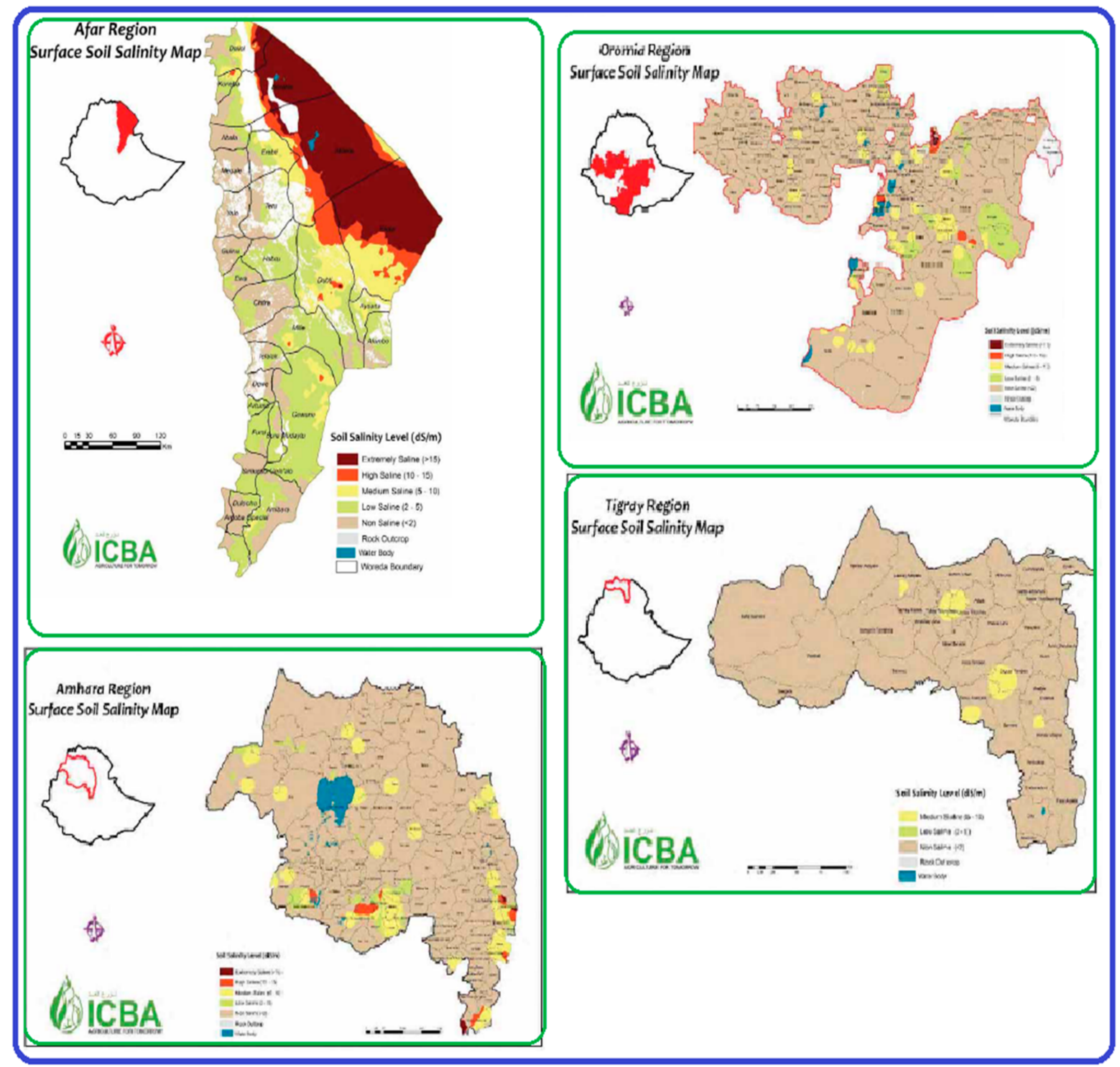

Figure 2. Surface salinity classes $(0-30 \mathrm{~cm})$ of Afar, Amhara, Oromia, and Tigray regions of Ethiopia [5].

The Rift Valley Zones and the south-eastern (Somali) lowlands are among the most valuable agricultural areas as they offer a considerable promise for multiple cropping. Most of the irrigated State Farms which produces export crops such as cotton, sugar cane, citrus fruits, banana, and vegetable crops are situated in the Rift Valley Zone and lower Wabi Shebelle basin of Gode. In these areas, small-scale cultivation with a canal irrigation system from the Shebelle River is introduced. Yet sizeable regions in this zone are being converted to salt-affected soils annually at an alarming rate [3-5,29].

The magnitudes of salt-affected soils are high to the extent that the establishment and growth of crops and other plants failed utterly. This implies that expansion of large-scale irrigation schemes in the Wabi Shebelle and other river basins without appropriate management of salts may result in further development of soil salinity and sodicity problems leading to complete loss of land value as experienced in the Awash River Basin in the Rift Valley $[4,5,29,30]$. Therefore, installation of adequate drainage systems in irrigated areas is a pre-condition for sustainable crop production. 


\section{Influence of Salt Affected Soils on Crop Production and Soil Productivity 4.1. Influence of Salt-Affected Soils on Crop Production}

Plants in saline and sodic soils of arid regions grow in a predominantly delicate balance with their environment because the excessive presence of soluble salts and exchangeable sodium in these soils can negatively affect crop. Lack of proper management leads to reduced crop production or in severe cases complete crop failure followed by a decline in land value and subsequently made the land abandoned for agricultural use [31,32]. Salinity, therefore, adversely affects the seed germination, establishment of young seedlings, and plant growth by decreasing the ease with which they may take up water and nutrients from the soil solution [33]. The plants can die from water stress or drought in moist soil if the salt concentration develops high enough in the field $[34,35]$. Increasing salinity levels beyond threshold level of plants negatively affect crop yields [36-38]. The studies conducted in Ethiopia have shown that dry biomass yield and grain yield of five Quinoa genotypes is negatively affected by increasing salinity levels (Figure 3) [39].
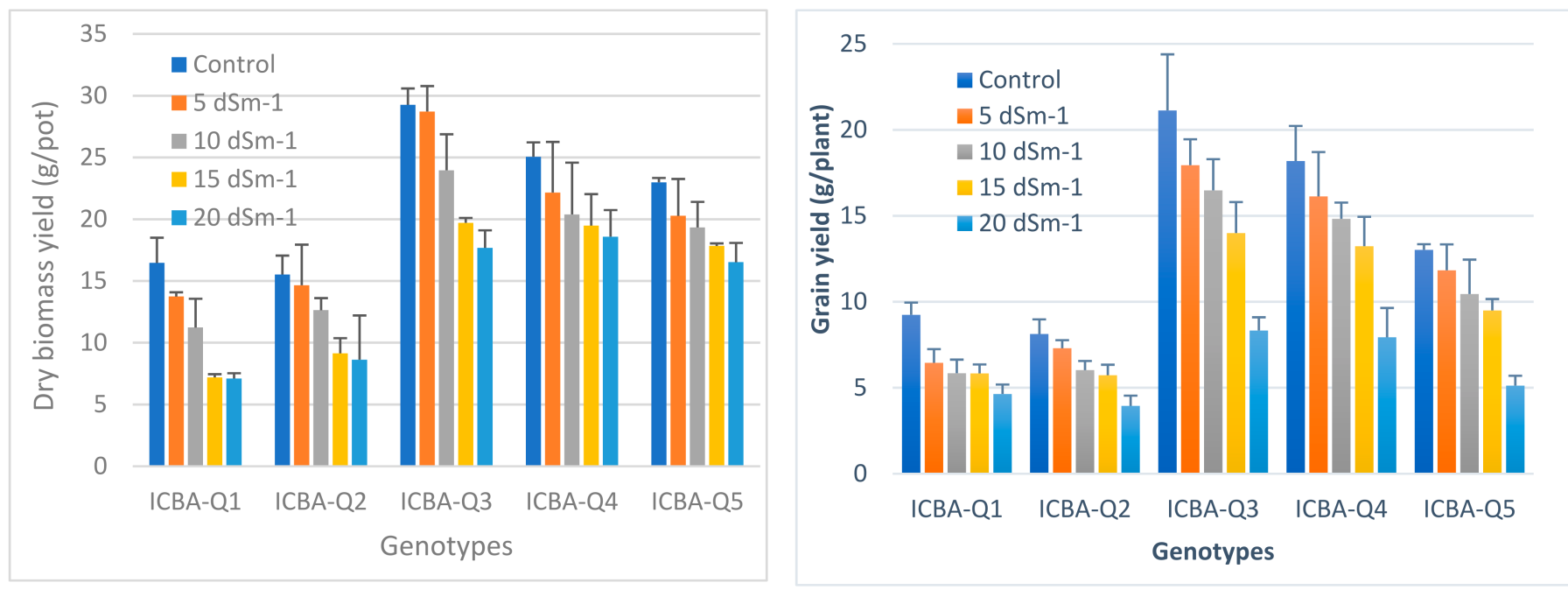

Figure 3. Dry biomass yield and grain yield of five quinoa genotypes as affected by different salinity levels [39].

Many researchers have indicated that the overall accumulation of salt in the plant root zone is a challenge to plant growth and development through increasing osmotic pressure of the soil solution; inducing ion toxicity and nutrient imbalance, and unfavored soil physical properties [31,32]. A yield reduction of $5 \%$ for broad bean and $20 \%$ for lentils were observed at an ECe of $2.0 \mathrm{dSm}^{-1}$. When the salinity level was increased to $3.1 \mathrm{dSm}^{-1}$, the corresponding yield reductions were $15 \%$ and $95 \%$, respectively [3]. The high salinity causes reduction in the dry matter yield of Alfalfa and Rhodes grass while the leaf-to-stem ratio increases, affecting forage quality [40]. A matrix plot of onion yield showed a reduced trend as the soil's pH, EC, and ESP increased [41]. In addition to this, increasing salt stress delayed the germination of Rhodes grass because higher salinity causes poor cell elongation resulting from reduced turgor, cell volume, and cell growth (Figure 4) [42]. Therefore, increasing salinity levels can decrease grain and biomass yield due to poor seed establishment $[24,28,35]$. 


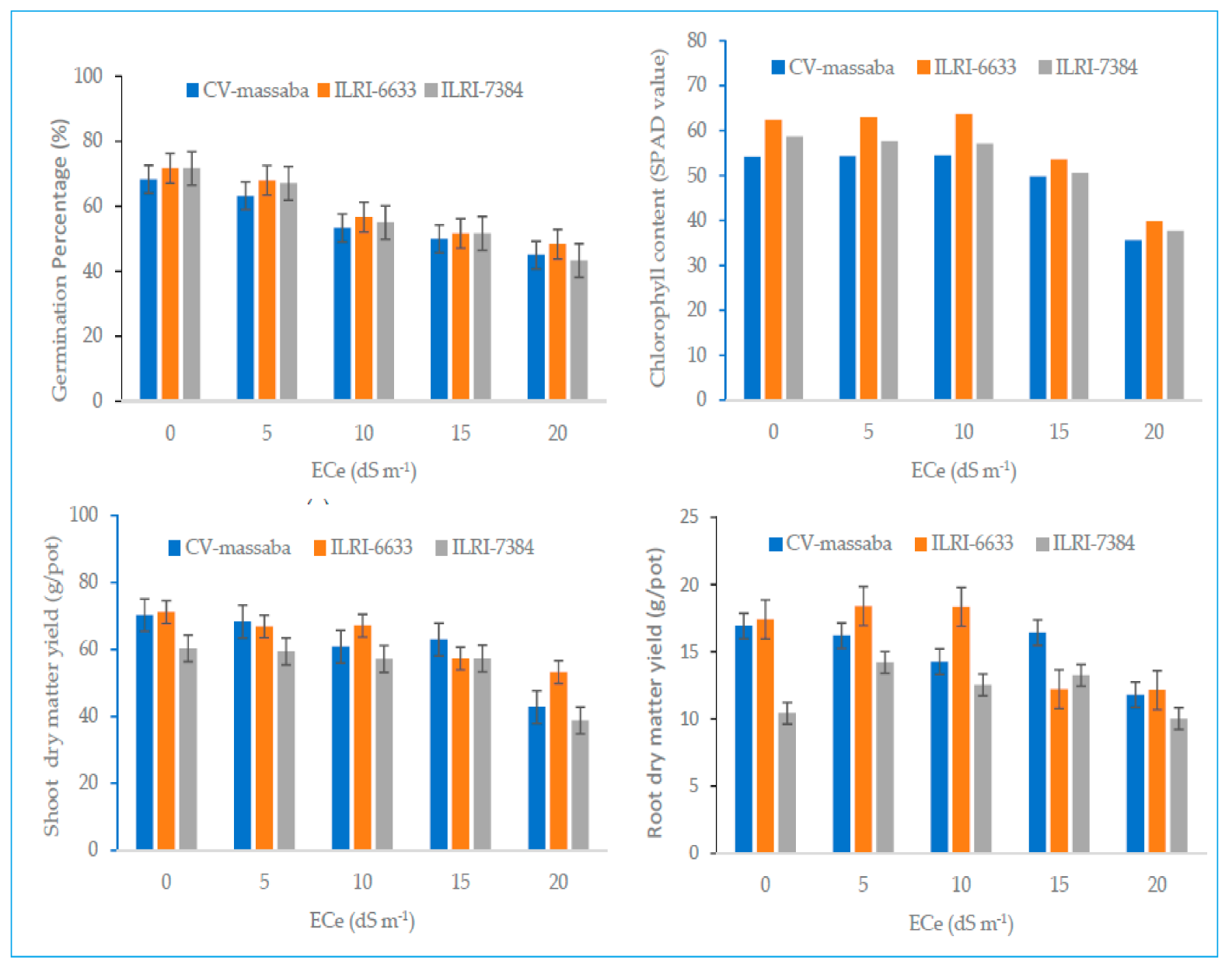

Figure 4. Influence of different salinity levels on germination percentage; chlorophyll content; shoot and root dry matter yield of three selected Rhodes grass species [42].

\subsection{Influence of Salt-Affected Soils on Soil Productivity}

Salt-affected soils negatively influence the soil's physical and chemical fertility, decreasing soil productivity [43]. Alteration of soil physical properties resulting from the swelling and dispersion of colloidal soil particles caused by the presence of excess sodium, and finally results in poor water and air circulation, water-holding capacity, restricted root penetration, and seedling development problems [32,33]. The sodicity increases with the bulk density because of the dispersive action of sodium on soil particles resulting in soil compaction, changing the pore size distribution, and decreasing the total volume of soil [24]. The increased soil sodium content affect the aggregation stability, thereby promoting clay from dispersing [8]. Second, the extent of exchangeable sodium percentage results in poor aggregation effects on bulk density, hydraulics conductivity, and mean weight diameter, which seriously affected crop productivity (Figures 5 and 6). 


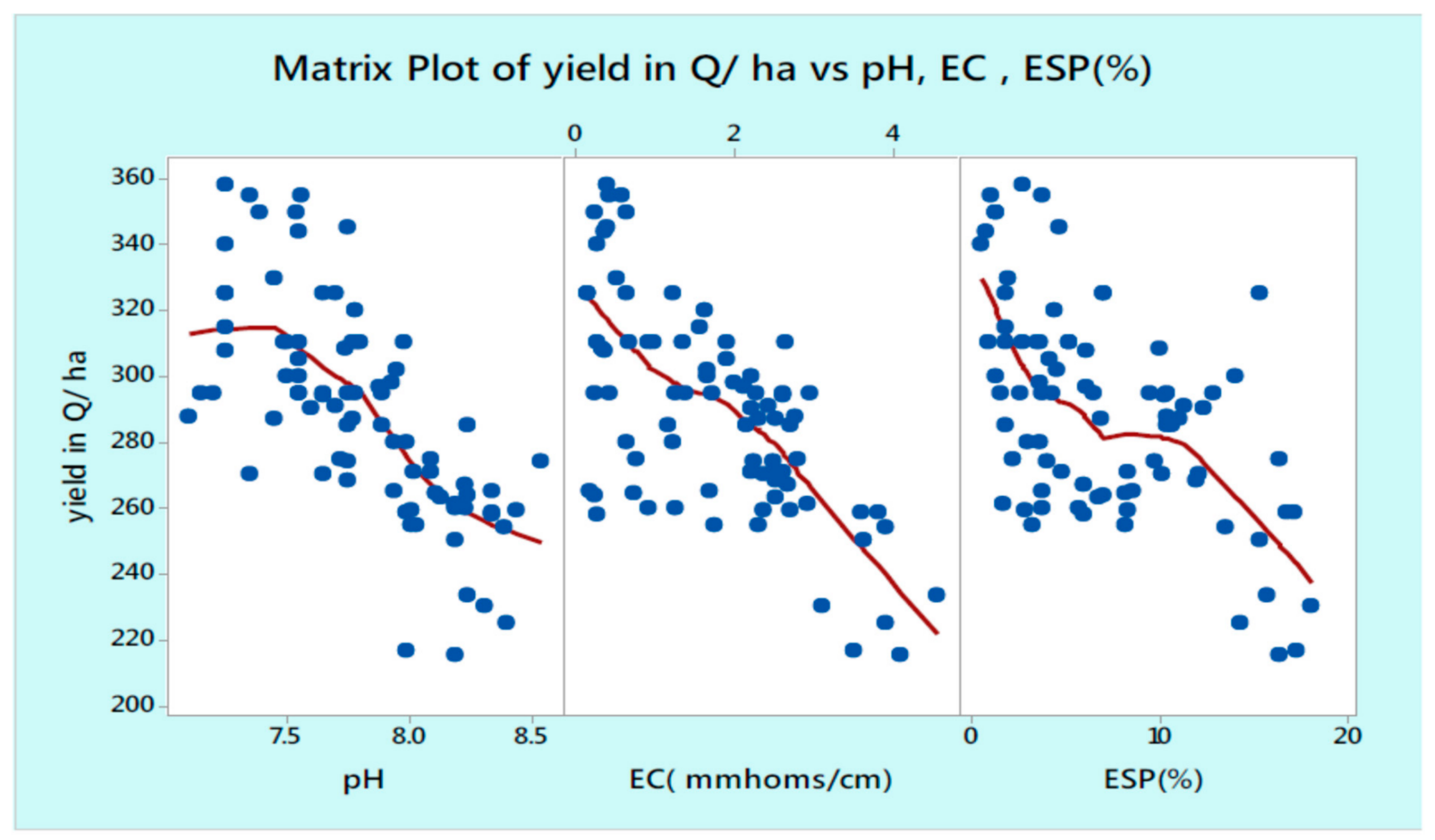

Figure 5. Matrix plot of onion crop yield vs. soil pH, total soluble salts (EC) and exchangeable sodium percentage (ESP) [41].
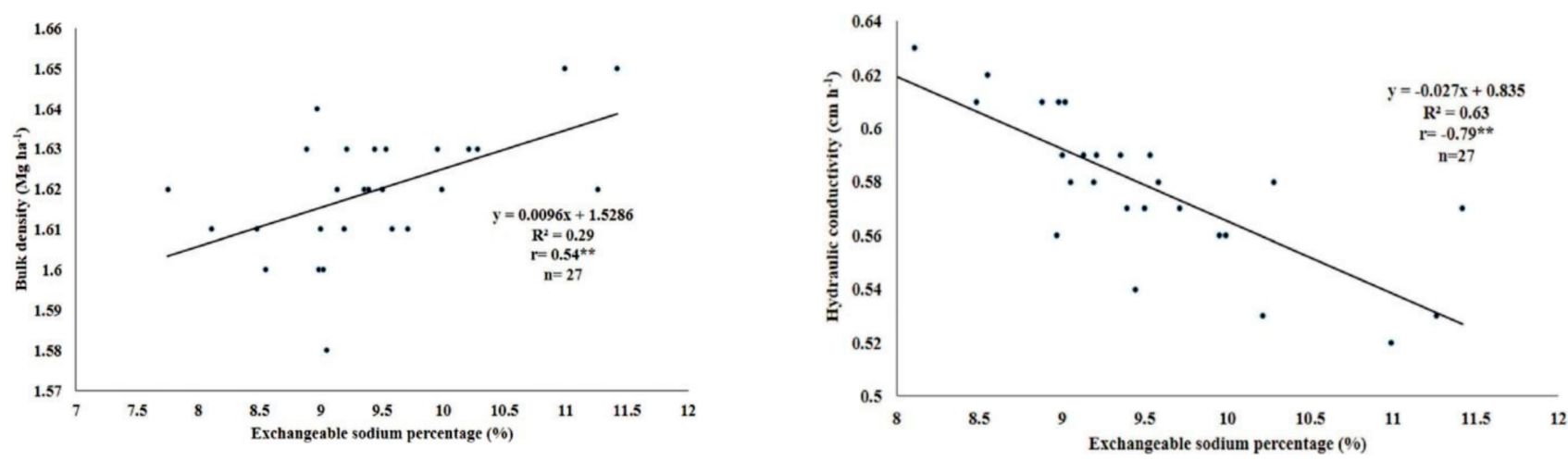

Figure 6. Relationship between ESP to soil bulk density, and hydraulic conductivity $(* *=$ highly significant correlation) [44].

The possible mechanisms responsible for the reduced permeability and aeration of alkali soils are the swelling and dispersion of clay and organic matter particles and their migration, causing the clogging of soil pores. As a rule, the swelling and dispersion of colloidal soil particles attributed to the presence of high exchangeable sodium results in restricted water infiltration and movement, limited air movement (aeration property), reduced root penetration, and increased crust formation as to decrease the emergence of seedlings. This mainly affects the inhabitants, structure, and activity of beneficial soil microorganisms through the osmotic effects of soluble salts or toxicity of specific ions of such soils. Therefore, some effects of salts on microbial processes will have large suggestions for SOM dynamics, ecosystem biogeochemical cycling, and plant nutrition $[45,46]$.

\section{Effects of Salt-Affected Soils on Crop Production}

Saline soils are recognized visually by the presence of white crusts of salts on the soil surface during dry weather formed through evaporation. Saline soils are generally flocculated, well-structured with permeability equal to or higher than that of normal soils. Sodic soils are typically poorly structured, characterized by the presence of dispersed colloidal clays and organic matter in the topsoil. The surface horizons of sodic soils are exceptionally 
compact and cemented, and puddles of water on these soils are usually turbid, brownish black in color (Na-humus) and a shiny black crust of film of dry colloidal substance remains on the surface of the soil when dry. The presence of dispersed colloidal clays of smectites group of clay minerals and organic matter on the soil surface is attributed to swelling, physically damaging the soil structure leading to low permeability and drainage problems. This causes low infiltration rates, poor aeration, and surface crusting, which makes it difficult to till and difficulty for plant roots to penetrate through.

Salinization of soils has tremendous challenges for crop production and soil productivities, resulting in uncertain and unstable livelihood security, low economic returns, and poor quality of life [11,47]. Excess soluble salts and sodium hazards of soils affect the metabolism of soil flora and fauna, ultimately damage the soil life, altering fertile and productive soils into abandoned soils, especially in irrigated lowlands of the rift valley system $[5,11]$. Generally, soil salinity and sodicity affects almost all aspects of plant development, including germination, vegetative growth, and reproductive development under marginal environmental conditions [48]. The Amibara irrigation scheme was a cotton cultivating area for more than 40 years. However, due to poor irrigation water management (excessive or low irrigation, irrigation with saline groundwater, no drainage, etc.), $35 \%$ of the farmland is now abandoned resulting in decline of the cotton and sugarcane production in the state farms [27]. Similarly, Metehara sugarcane farmland is highly affected by salinity and sodicity problems [49]. Soil salinity and sodicity have caused poor development of crops, which resulted in a reduction of crop yields.

The management and reclamation of soil salinity and sodicity need higher investments, especially engineering rehabilitation methods that are impractical for smallholder farmers for economic and technical reasons [3,12]. In addition to this, soil salinity and sodicity have exerted both direct and indirect effects on the livelihoods of producers in Amibara, Dubti, Zeway-Dugda, Kewet, and Raya-Alamata [50]. The soil salinity and sodicity has directly affected $29.41 \%$ of farmers, decreasing farm productivity (52.94\%) and household income $(8.82 \%)$ in Amibara and Dubti irrigated areas [11]. At the same time, the indirect effects were increasing food insecurity (29.41\%), decreasing employment opportunity $(3.92 \%)$, increasing landlessness (45.10\%), increasing dependency $(5.88 \%)$, and increasing food insecurity $(8.82 \%)$ (Table 3). Therefore, rehabilitation and management of saline and sodic soils are very essential to improve the agricultural productivities of salt-affected soils for the cultivation of food and fodder crops.

Table 3. Direct and indirect effects of salinity on sample respondents [11].

\begin{tabular}{|c|c|c|c|c|c|c|c|}
\hline \multirow{2}{*}{ Direct Effects } & \multicolumn{2}{|c|}{ Amibara } & \multicolumn{2}{|c|}{ Dubti } & \multicolumn{2}{|c|}{ Total } & \multirow{2}{*}{$x^{2}$ Value } \\
\hline & Freq. & $\%$ & Freq. & $\%$ & Freq. & $\%$ & \\
\hline $\begin{array}{l}\text { Abandoning } \\
\text { farmland }\end{array}$ & 14 & 20.90 & 16 & 45.71 & 30 & 29.41 & \\
\hline $\begin{array}{l}\text { Decreasing farm } \\
\text { productivity }\end{array}$ & 40 & 59.70 & 14 & 40.00 & 54 & 52.94 & $10.046^{*}$ \\
\hline \multirow[t]{2}{*}{$\begin{array}{l}\text { Decreasing } \\
\text { household income }\end{array}$} & 8 & 11.94 & 1 & 2.86 & 9 & 8.82 & \\
\hline & \multicolumn{4}{|c|}{ Indirect effects } & & & \\
\hline $\begin{array}{l}\text { Increasing food } \\
\text { insecurity }\end{array}$ & 22 & 32.84 & 8 & 22.86 & 30 & 29.41 & \multirow{4}{*}{8.130} \\
\hline $\begin{array}{l}\text { Decreasing } \\
\text { employment }\end{array}$ & 3 & 4.48 & 1 & 2.86 & 4 & 3.92 & \\
\hline $\begin{array}{l}\text { Increasing } \\
\text { landlessness }\end{array}$ & 27 & 40.30 & 19 & 54.23 & 46 & 45.10 & \\
\hline $\begin{array}{l}\text { Increasing } \\
\text { dependency }\end{array}$ & 6 & 8.96 & 0 & 0.00 & 6 & 5.88 & \\
\hline
\end{tabular}




\section{Reclamation and Management Strategies}

The amendment of saline and excess sodium concentrated soils needs to eliminate or replace soluble salts and exchangeable sodium. This can be done in many ways, including physical, chemical, and biological approaches. Depending on the local conditions and available resources, a suitable reclamation method can be selected [3,42]. If the modifications are expensive, smallholder farmers could not afford to spend for soil reclamation. Nowadays, an integrated approach combines different methods of saline and sodic soil reclamation and management. Currently, several organic and inorganic amendments (e.g., gypsum, phosphogypsum, $\mathrm{H}_{2} \mathrm{SO}_{4}$, organic residues), land and water management practices (e.g., land leveling, irrigation and drainage management), and biological methods (e.g., genetic use of halophytic traits, utilization of plant-microbe associations) are being used to improve productivities of salt-affected soils [3,5,41,42,51-55].

\subsection{Chemical Approach}

Organic and inorganic amendments mainly used for reclamation of excess sodium concentrated soils can be depending on the nature of the soils, and the cost of chemical amendment considered [24]. In Ethiopia, several methods are being used to rehabilitate saline and sodic soils. These include: (i) chemical amendments (e.g., gypsum, phosphogypsum, $\mathrm{H}_{2} \mathrm{SO}_{4}$ ), (ii) organic amendments (e.g., manure, biochar, pressmud, straw or hay), and fertilizer applications (Figure 7). Sodicity of the soil problem has to exchange excessive amounts of $\mathrm{Na}^{+}$from the soil CEC with $\mathrm{Ca}^{2+}$ reclaimed through the addition of Ca-enriched materials $[41,56]$, and then ensure $\mathrm{Na}^{+}$leaching from the soil profile by irrigation or natural leaching practices [18,57]. The application of $50 \%$ gypsum plus $50 \%$ $\mathrm{H}_{2} \mathrm{SO}_{4}$ improves calcareous-sodic soil and cotton yield compared to other treatments at the Melka-Sadi irrigation scheme (Table 4) [56].

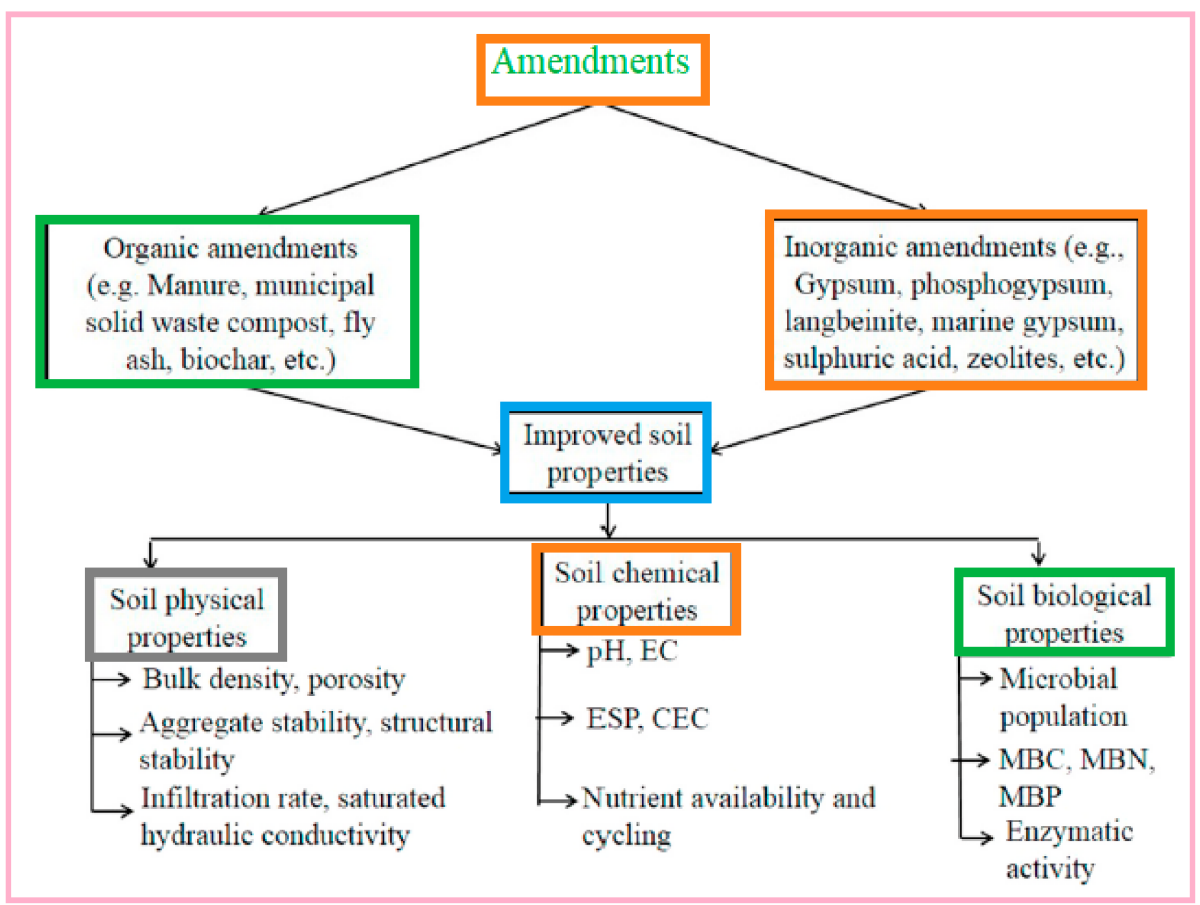

Figure 7. Advantageous effects of different types of amendments for salt-affected soils [55]. 
Table 4. Effects of the different chemical amendments (Gypsum and $\mathrm{H}_{2} \mathrm{SO}_{4}$ acid) on the productivities calcareous-sodic soil and seed cotton yield at Melka-Sadi irrigation scheme [56].

\begin{tabular}{|c|c|c|c|c|c|c|c|c|c|c|c|}
\hline \multirow[b]{2}{*}{$\begin{array}{l}\text { Treat- } \\
\text { ment }\end{array}$} & \multicolumn{5}{|c|}{2010} & \multicolumn{5}{|c|}{2011} & Avg. \\
\hline & SCM & PH & $\mathbf{A B N}$ & ABW & $\begin{array}{l}\mathrm{Yq} \\
\mathrm{ha}^{-1}\end{array}$ & SCM & PH & $\mathbf{A B N}$ & ABW & $\underset{h^{-1}}{\mathrm{Yq}}$ & $\begin{array}{c}\mathrm{Yq} \\
\mathrm{ha}^{-1}\end{array}$ \\
\hline T1 & 492.0 & 61.6 & 7.7 & 3.63 & 15.4 & 501.37 & 71.33 & 16.63 & 4.71 & 18.04 & 16.71 \\
\hline $\mathrm{T} 2$ & 551.6 & 66.4 & 9.3 & 4.04 & 17.9 & 567.67 & 85.73 & 22.70 & 5.15 & 27.85 & 22.90 \\
\hline T3 & 611.6 & 71.0 & 14.6 & 4.53 & 31.3 & 571.65 & 87.00 & 25.43 & 5.58 & 31.20 & 31.28 \\
\hline $\mathrm{T} 4$ & 578.0 & 69.2 & 13.2 & 4.09 & 24.9 & 578.00 & 89.1 & 22.10 & 4.77 & 27.68 & 26.31 \\
\hline $\mathrm{CV}$ & 3.9 & 5.9 & 12.2 & 11.90 & 11.3 & 11.75 & 5.75 & 8.33 & 13.40 & 5.30 & 11.56 \\
\hline $\begin{array}{c}\text { LSD = } \\
5 \%\end{array}$ & $44.16^{*}$ & $7.97 *$ & 2.74 * & NS & $5.01 *$ & NS & 9.50 * & $3.61 *$ & NS & 2.77 * & 3.24 * \\
\hline \multirow{3}{*}{\multicolumn{2}{|c|}{ Treatment }} & \multirow{3}{*}{$\begin{array}{l}\text { Soil } \\
\text { depth }\end{array}$} & \multirow{2}{*}{\multicolumn{3}{|c|}{$\begin{array}{l}\text { Before apply chemical and } \\
\text { planting }\end{array}$}} & \multirow{2}{*}{\multicolumn{3}{|c|}{$\begin{array}{l}\text { After apply chemical } \\
2010 \text { at } 1 \text { st harvesting }\end{array}$}} & \multirow{2}{*}{\multicolumn{3}{|c|}{$\begin{array}{l}\text { After apply chemical } \\
2011 \text { at } 2 \text { nd harvesting }\end{array}$}} \\
\hline & & & & & & & & & & & \\
\hline & & & $\mathrm{pHe}$ & $\mathrm{ECe}(\mathrm{ds} / \mathrm{m})$ & ESP (\%) & $\mathrm{pHe}$ & $\begin{array}{c}\text { ECe } \\
(\mathrm{ds} / \mathrm{m})\end{array}$ & ESP (\%) & $\mathrm{pHe}$ & $\begin{array}{c}\text { ECe } \\
(\mathrm{ds} / \mathrm{m})\end{array}$ & ESP (\%) \\
\hline \multirow{2}{*}{\multicolumn{2}{|c|}{$\mathrm{T} 1$}} & $0-30$ & 8.4 & 12.35 & 33.83 & 8.2 & 11.77 & 28.19 & 8.1 & 10.77 & 27.19 \\
\hline & & $30-60$ & 8.3 & 9.55 & 34.10 & 8.3 & 12.30 & 27.35 & 8.2 & 14.30 & 27.25 \\
\hline \multirow{2}{*}{\multicolumn{2}{|c|}{$\mathrm{T} 2$}} & $0-30$ & 8.6 & 13.67 & 34.26 & 7.8 & 5.60 & 25.28 & 7.9 & 5.20 & 23.28 \\
\hline & & $30-60$ & 8.5 & 11.06 & 34.27 & 8.0 & 6.00 & 25.61 & 7.9 & 6.00 & 23.55 \\
\hline \multirow{2}{*}{\multicolumn{2}{|c|}{ T3 }} & $0-30$ & 8.5 & 14.33 & 36.51 & 7.6 & 6.30 & 25.55 & 7.5 & 5.40 & 20.55 \\
\hline & & $30-60$ & 8.4 & 13.04 & 40.02 & 7.7 & 5.97 & 24.8 & 7.6 & 5.45 & 20.80 \\
\hline \multirow{2}{*}{\multicolumn{2}{|c|}{$\mathrm{T} 4$}} & $0-30$ & 8.4 & 11.44 & 28.25 & 7.9 & 7.43 & 22.45 & 7.8 & 7.43 & 22.35 \\
\hline & & $30-60$ & 8.3 & 9.24 & 31.78 & 7.8 & 5.97 & 26.99 & 7.8 & 6.14 & 24.09 \\
\hline
\end{tabular}

* Significant at $p \leq 0.05$, NS; Non-significant, SCM; stand count at Maturity, PH; plant height, ABN; average ball number, ABW; average ball weight, Y q ha; yield quintal per hectare, T1; control or no treatment, T2; $100 \%$ Gypsum (full doze), T3; 50\% Gypsum and $50 \% \mathrm{H}_{2} \mathrm{SO}_{4}$ acid, $100 \%, \mathrm{~T} 4 ; 100 \% \mathrm{H}_{2} \mathrm{SO}_{4}$ acid (full doze), CV; coefficient variance, LSD; List significant difference.

The application of gypsum with halophytic forage crops has proved to be an effective amelioration strategy to enhance productivities of saline-sodic soils in Golina-Addisalem irrigation scheme of Raya Kobo valley (Table 5) [54]. Similarly, combined application of 20 tha $^{-1}$ farmyard manure $+7 \%$ gypsum requirements is beneficial to improving rice's productivity in saline-sodic soil of Amibara area [58]. The application of 5 tha- 1 compost integrated with 4 tha ${ }^{-1}$ gypsum improves onion yield and enhances the productivities of saline-sodic soils (Table 6 and Figures 8 and 9) [41]. The application of gypsum improves soil physical properties (soil structure), (ii) decrease sodium hazard from soil matrix, (iii) maximize clay flocculation, and (iv) enhance water-air relations [15,27]. 
Table 5. Influence of gypsum and halophytic forage grasses on soluble salt and sodium hazard at soil depth of $25 \mathrm{~cm}$ [54].

\begin{tabular}{|c|c|c|c|c|c|c|c|}
\hline \multirow{2}{*}{$\begin{array}{c}\text { Gypsum } \\
\text { Levels }\end{array}$} & \multirow{2}{*}{ BACA } & \multicolumn{3}{|c|}{ After 1st Harvest } & \multicolumn{3}{|c|}{ After 2} \\
\hline & & $\mathbf{0 ~ H}$ & PAG & CGG & $\mathbf{0} \mathbf{H}$ & PAG & CGG \\
\hline & \multicolumn{7}{|c|}{ Exchangeable sodium percentage (\%) } \\
\hline $0 \%$ & \multirow{4}{*}{55.03} & 56.64 & 45.29 & 44.45 & 57.37 & 39.99 & 38.60 \\
\hline $75 \%$ & & 39.56 & 26.71 & 25.97 & 36.88 & 18.59 & 17.63 \\
\hline $100 \%$ & & 31.64 & 17.96 & 17.41 & 27.97 & 13.73 & 13.55 \\
\hline $125 \%$ & & 26.06 & 11.99 & 12.41 & 22.23 & 8.94 & 8.93 \\
\hline LSD & & \multicolumn{3}{|c|}{1.17} & \multicolumn{3}{|c|}{0.37} \\
\hline $\mathrm{CV}(\%)$ & & \multicolumn{3}{|c|}{2.33} & \multicolumn{3}{|c|}{0.86} \\
\hline \multicolumn{8}{|c|}{ Electrical conductivity $\left(\mathrm{dSm}^{-1}\right)$} \\
\hline $0 \%$ & \multirow{4}{*}{20.00} & 19.92 & 14.90 & 14.59 & 20.10 & 11.92 & 11.90 \\
\hline $75 \%$ & & 11.87 & 8.18 & 8.37 & 11.05 & 7.28 & 7.34 \\
\hline $100 \%$ & & 10.63 & 7.20 & 7.17 & 10.39 & 6.38 & 6.33 \\
\hline $125 \%$ & & 9.11 & 5.55 & 6.00 & 8.73 & 4.13 & 4.62 \\
\hline LSD & & & 0.645 & & & 0.28 & \\
\hline $\mathrm{CV}(\%)$ & & & 3.7 & & & 3.58 & \\
\hline
\end{tabular}

LSD: least significant difference; CV: coefficient of variation; $0 \mathrm{H}$ : no halophytic grass plantation; $\mathrm{CGG}=$ Chloris gayana grass; PAG = Panicum antidotale grass; BACA: Before applying chemical amendments.

Table 6. Influence of compost combined with gypsum on onion yield under saline-sodic soil condition of Bora district of Oromia region [41].

\begin{tabular}{|c|c|c|}
\hline Treatments & Mean Crop Yield (Q/ha) & Relative Yield Advantage \\
\hline \multicolumn{3}{|l|}{ Main effect for compost } \\
\hline 0 (control) & $237.18^{f}$ & 0.00 \\
\hline $2.5 \mathrm{t} /$ ha compost & $235.03^{f}$ & 1.20 \\
\hline $5.0 \mathrm{t} /$ ha compost & 275.55 & 16.18 \\
\hline \multicolumn{3}{|l|}{ Main effect of Gypsum } \\
\hline 2 t/ha Gypsum & $284.44^{\mathrm{e}}$ & 19.93 \\
\hline 4 t/ha Gypsum & $325.00^{\mathrm{d}}$ & 37.03 \\
\hline \multicolumn{3}{|l|}{ Interaction effects } \\
\hline $2.5 \mathrm{t} /$ ha compost $+2 \mathrm{t} /$ ha Gypsum & $355.77^{c}$ & 50.00 \\
\hline $2.5 \mathrm{t} /$ ha compost $+4 \mathrm{t} /$ ha Gypsum & $396.40^{\mathrm{b}}$ & 67.13 \\
\hline $5.0 \mathrm{t} /$ ha compost $+2 \mathrm{t} /$ ha Gypsum & $406.70^{b}$ & 71.47 \\
\hline $5.0 \mathrm{t} /$ ha compost $+4 \mathrm{t} /$ ha Gypsum & $430.33^{a}$ & 85.23 \\
\hline LCD (0.05) & 25.03 & - \\
\hline CV $(\%)$ & 6.05 & - \\
\hline t-test & $* * * *$ & - \\
\hline
\end{tabular}



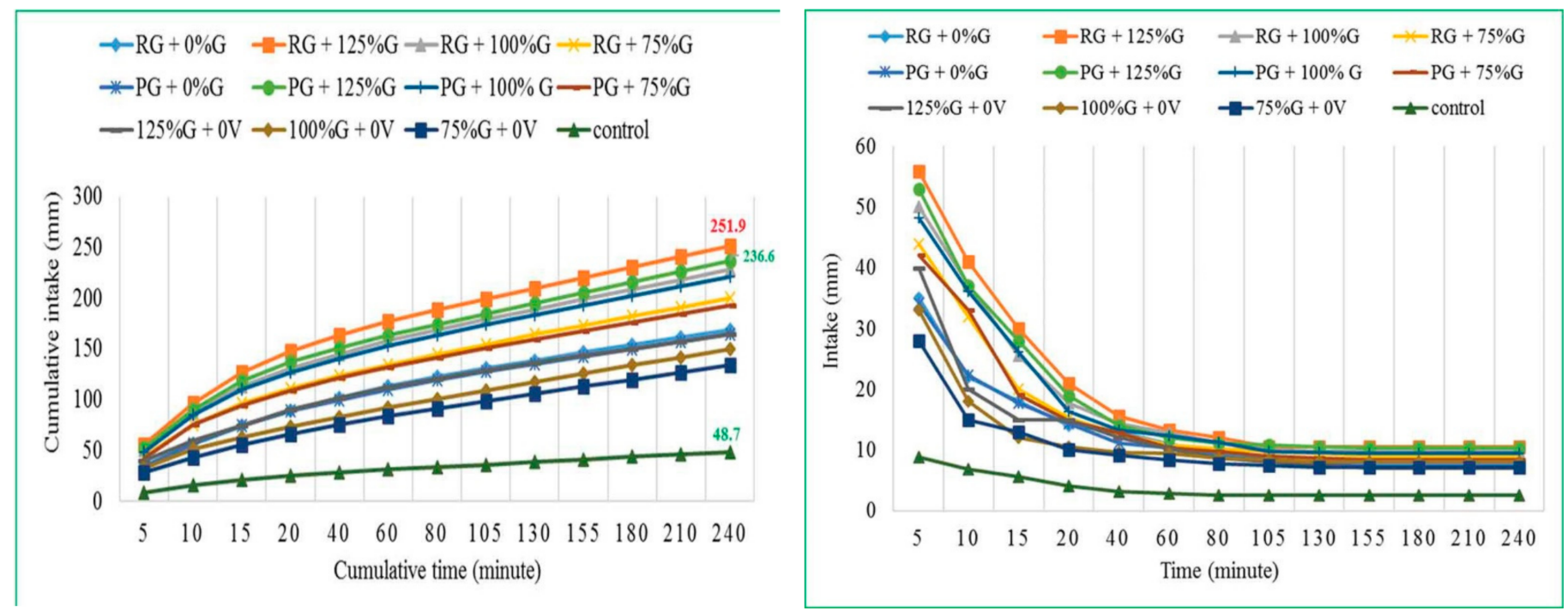

Figure 8. Infiltration (intake) and cumulative infiltration vs. time under saline-sodic soil condition of Raya Kobo valley [54].

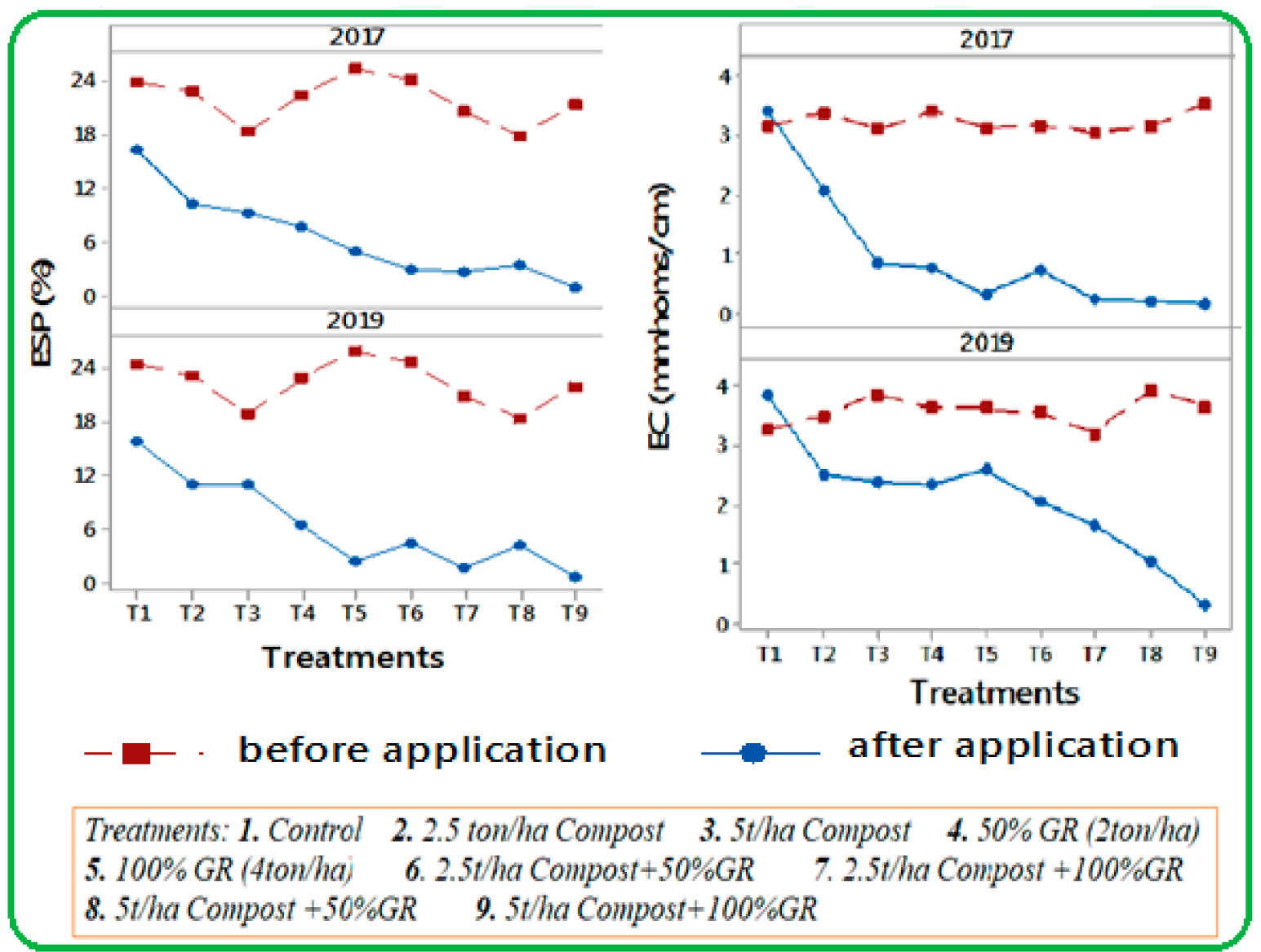

Figure 9. Changing of soil chemical properties status (ECe and ESP) from 2017-2019 after application of gypsum and compost [41].

Sulphuric acid is one of the acids to reclaim calcareous-sodic soils. After applying to a soil containing calcium carbonate, it immediately reacts to form calcium sulfate, thereby providing indirectly soluble calcium [59]. The sulfuric acid improves calcareous-sodic soils through soluble calcium carbonate present in the sodic soil. [56] confirmed 50\% gypsum and $50 \% \mathrm{H}_{2} \mathrm{SO}_{4}$ acid are the better amendment of calcareous-sodic soils than a total dose of 
gypsum application for cotton production [24]. Combined chemical modification (gypsum and sulfuric acid) with nitrogen fertilizer improves rice production under saline-sodic soil of the Amibara areas [53].

The addition of different organic amendments, namely: farm manure, poultry manure, compost, and press mud, could be efficient in enhancing plant growth through improving on physical, chemical, and biological properties of saline, saline-sodic and sodic soils [25,60]. The application of filter cake and bagasse on calcareous sodic soils can also improve crop nutrient use, indices agronomic, agro-physiological, and apparent recovery efficiency of nitrogen and phosphorus (Figure 10) [34]. The combined application of biochar and gypsum influenced soil chemical properties, seed per panicle, increased quality, and quantity of grain yield of wheat crop under saline-sodic soil condition of Amibara [61] Biochar is produced by heating any organic waste materials at high temperatures through the process of pyrolysis. It is rich in organic matter and influential in improving physical, chemical (by increasing $\mathrm{Ca}, \mathrm{Mg}$ and $\mathrm{K}, \mathrm{CEC}$, etc.), and saline-sodic and sodic soils [62]. In addition to this, biochar has been shown to maximize porosity, resulting in improved available water and reduced bulk density of saline-sodic and sodic soils [61]. Generally, biochar improves the habitat and conditions of high sodium-containing soils for microbial associations and diversity and significantly increases crop production and soil productivity.
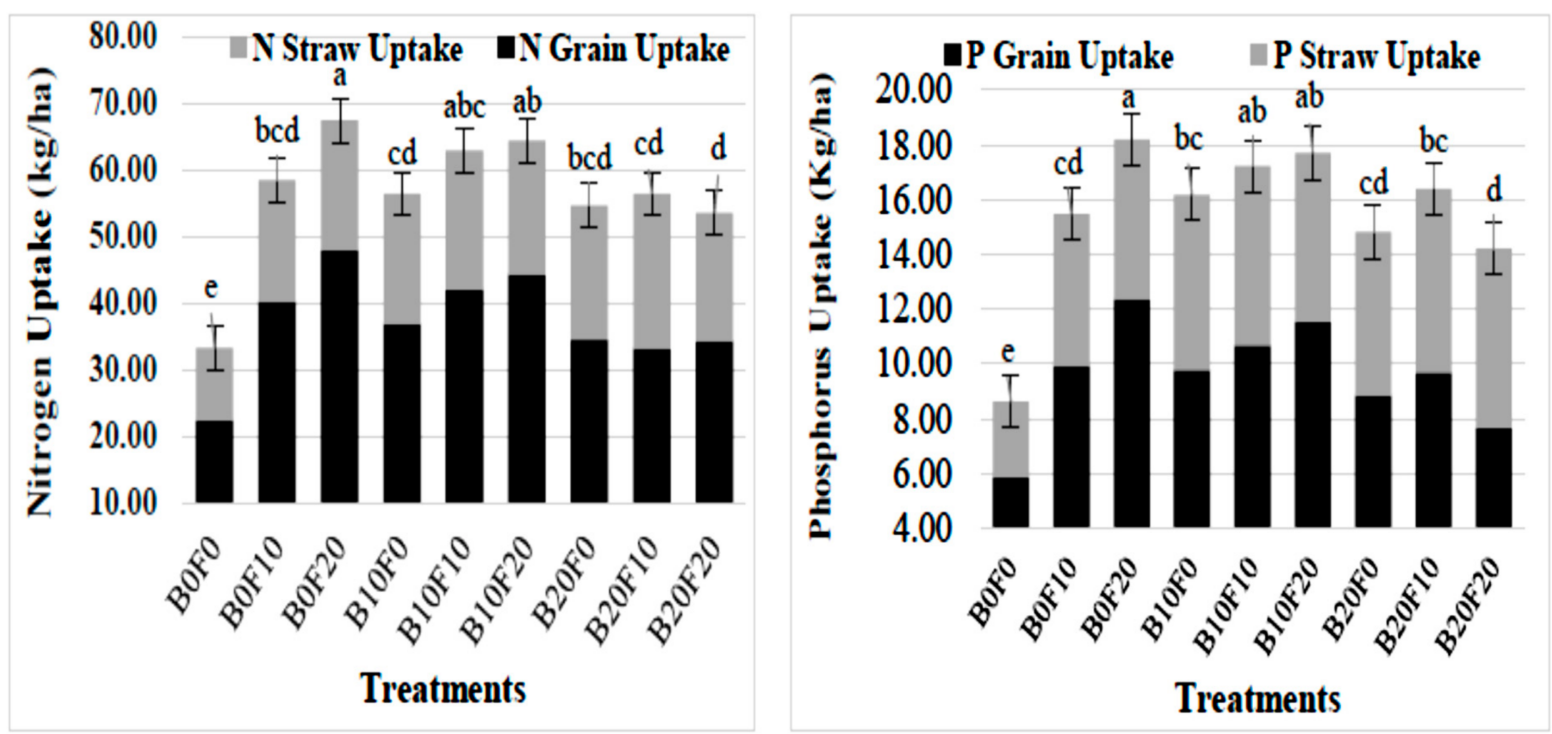

Figure 10. Influence of filter cake (F) and bagasse (B) on rice $\mathrm{N}$ and $\mathrm{P}$ uptake under calcareous sodic soils at Amibara [34].

\subsection{Biological Approaches}

With the intention of fast restoring excess sodium concentration soils, gypsum is primarily used as a chemical amendment. On the other hand, physical and chemical approaches for reclamation of salt-affected soils are not cost-effective [32,54]. Thus phytoremediation is an effective technique, as an alternative to chemical amendment, primarily by planting salt-tolerant plant species $[39,42,52]$. The phytoremediation of salt-affected soils is capable of maximizing the degree of calcite dissolution by the soil-root interface process, resulting in an increased level of $\mathrm{Ca}^{2+}$ in the soil solution [63]. In Ethiopia, breeding methods such as the selection and establishment of salt-resistant genotypes by local breeding [64] have been effectively applied for the mitigation of salt stress through selecting and screening tolerant genotypes. Research results show that increasing density can result in reduced productivity. It may also increase salt accumulation in plant tissues [52] (Table 7). 
Table 7. Soil ECe and ESP decrease through phytoremediation using different grasses species (i initial, $\mathrm{f}$ final and $\mathrm{r}$ reduction) [52].

\begin{tabular}{|c|c|c|c|c|c|c|}
\hline Phytoremediation & $\begin{array}{c}\mathrm{ECe}_{\mathrm{i}} \\
\left(\mathrm{dS} \mathrm{m}^{-1}\right)\end{array}$ & $\begin{array}{c}\mathrm{ECe}_{\mathrm{f}} \\
\left(\mathrm{dS} \mathrm{m}^{-1}\right)\end{array}$ & $\mathrm{ECe}_{\mathrm{r}}(\%)$ & $\mathrm{ESP}_{\mathrm{i}}(\%)$ & $\operatorname{ESP}_{\mathrm{f}}(\%)$ & $\operatorname{ESP}_{\mathrm{r}}(\%)$ \\
\hline Cinchrus ciliaris & 16.00 & 4.73 & 70.55 & 25.14 & 10.24 & 59.27 \\
\hline Chloris gayana & 18.08 & 4.55 & 74.81 & 27.14 & 9.75 & 64.08 \\
\hline Panicum antidotale & 12.05 & 4.05 & 66.42 & 31.14 & 14.68 & 52.86 \\
\hline Sorghum sudanese & 9.81 & 4.65 & 52.60 & 21.14 & 13.08 & 38.13 \\
\hline
\end{tabular}

Different halophytes or salt-tolerant species might also be effective in restoring saltaffected ecosystems such as those in irrigated lands (Figure 11) [39,40,52]. Thus, the vegetation sequence of the salt-affected ecosystems is essential to improve many pedoconstraints such as (i) reduction in soil ESP and bulk density; (ii) improving soil organic matter (SOM) components, (iii) noticeably activate soil enzymatic processes as well as advance microbial abundance and diversity $[27,65]$.
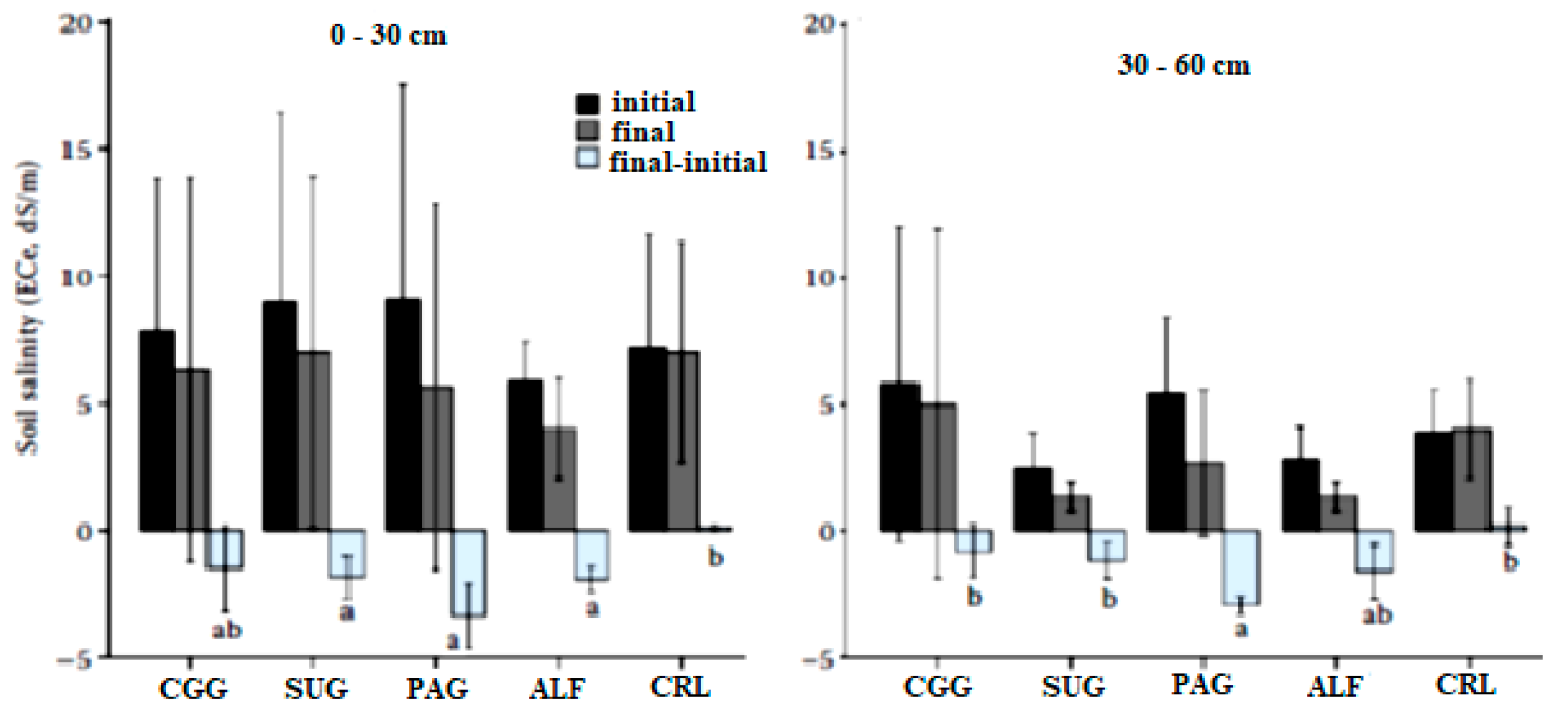

Figure 11. Soil ECe reduction through phytoremediation using different plants. CGG = Chloris gayana grass; SUG = Sudan-grass; PAG = Panicum antidotale grass; ALF = alfalfa legumes forage; CRL = control [40].

The latest studies have recommended metabolic bioengineering for generating salt stress-tolerant plants [66] because of their multiple valuable influences on salt-stressed plants. There are many constraints to salt tolerant gene identification in Ethiopia, such as high technologies and skilled human power limitations. Nonetheless, many authors reported screening of salt susceptible genotypes through conventional selection. Such screening is an effective tool to exploit genetic variation among crop genotypes $[3,64,67]$. Appeals such as germination-continued existence and seedling growth or biomass buildup have been the most regularly used principles for categorizing the salt tolerance of plants $[64,67,68]$. Based on this approach, many scholars have screened and selected salt-tolerant food and feed crops through conventional criteria (Table 8). 
Table 8. Selected salt tolerant food and feed crop genotypes.

\begin{tabular}{cccccc}
\hline Crop & $\begin{array}{c}\text { No. Genotypes } \\
\text { Tested }\end{array}$ & $\begin{array}{c}\text { Tolerant } \\
\text { Variety }\end{array}$ & ECe (dS/m) & $\begin{array}{c}\text { Yield } \\
\text { (Kg/ha) }\end{array}$ & Reference \\
\hline Wheat & 49 & ETBW-5879 & 13.00 & 3998.00 & {$[64]$} \\
Wheat & 200 & SANDALL-3 & 14.05 & 3709.02 & {$[69]$} \\
Sesame & 100 & EW-01 & 10.00 & 844.00 & {$[67]$} \\
Sorghum & 46 & Meko & 6.81 & 4722.00 & {$[68]$} \\
Teff & 42 & Kora & 8.23 & 2200.00 & {$[70]$} \\
Quinoa & 5 & ICBA Q3 & 20.01 & 2965.00 & {$[39]$} \\
\hline
\end{tabular}

\subsection{Physical Approach}

One of the critical functions of agricultural drainage is to remove surplus water caused by high precipitation, remove dissolved soluble salts from the soil system, and maintain the groundwater table. On the other hand, waterlogged salinity remains a severe problem in many productive areas [46,50]. Since the 1980s, Melka Sadi pilot drainage scheme in the Amibara irrigation project has increased awareness of the issues of rising groundwater tables under irrigation, which has resulted in localized waterlogging and considerable yield losses and salinization of once fully productive areas.

The analytical results of the soil survey of 1983 revealed that field numbers A02, A017, A025, and A027 were highly saline soil, with an ECe value ranging from 14.4 to $61.7 \mathrm{dSm}^{-1}$ [71]. Unfortunately, no recent data are available for these areas. However, physical observations suggest that the situation has gone from bad to worse. After establishing the subsurface (tile) drainage scheme and successive cropping of cotton since 1986, the salt concentration was greatly reduced as a function of leaching on those farmlands A02, A017, A025, and A027 (Table 9) [57]. This sub-surface drainage system was installed on 5 ha land in 1983-1984. The drainage pipes were installed at $2 \mathrm{~m}$ depth below soil surface with three drainage spacings i.e., $75 \mathrm{~m}, 40 \mathrm{~m}$, and $20 \mathrm{~m}[56,57]$.

Table 9. Impact of sub-surface drainage on soil salinity reduction from 1983 to 1989 [57].

\begin{tabular}{|c|c|c|c|c|c|c|}
\hline \multirow{2}{*}{$\begin{array}{l}\text { Sampling } \\
\text { Point }\end{array}$} & \multirow{2}{*}{$\begin{array}{l}\text { Soil Depth } \\
\text { (cm) }\end{array}$} & \multicolumn{2}{|c|}{1983} & \multicolumn{2}{|c|}{1989} & \multirow{2}{*}{$\begin{array}{l}\text { Reduction ECe } \\
\qquad(\mathrm{dS} / \mathrm{m})\end{array}$} \\
\hline & & $\mathrm{pH}$ & $\mathrm{ECe}(\mathrm{dS} / \mathrm{m})$ & $\mathrm{pH}$ & ECe $(\mathrm{dS} / \mathrm{m})$ & \\
\hline \multirow{4}{*}{$\mathrm{A} 02$} & $0-30$ & 7.3 & 35.6 & 7.8 & 6.7 & 28.9 \\
\hline & $30-60$ & 7.4 & 18.5 & 7.9 & 5.8 & 12.7 \\
\hline & $60-90$ & 7.3 & 16.0 & 8.0 & 6.9 & 9.1 \\
\hline & $90-120$ & 7.6 & 14.4 & 8.0 & 8.3 & 6.1 \\
\hline \multirow{4}{*}{ A017 } & $0-30$ & 7.2 & 37.1 & 7.8 & 2.1 & 35.0 \\
\hline & $30-60$ & 7.2 & 37.1 & 8.0 & 4.0 & 33.1 \\
\hline & $60-90$ & 7.2 & 12.3 & 7.4 & 3.59 & 8.71 \\
\hline & 90-120 & 7.6 & 12.3 & 7.2 & 4.2 & 8.10 \\
\hline \multirow{4}{*}{ A025 } & $0-30$ & 7.4 & 61.7 & 8.1 & 0.55 & 61.15 \\
\hline & $30-60$ & 7.6 & 39.1 & 8.0 & 0.44 & 38.66 \\
\hline & $60-90$ & 7.6 & 25.8 & 8.0 & 0.36 & 25.44 \\
\hline & $90-120$ & 7.6 & 21.6 & 7.8 & 0.57 & 21.03 \\
\hline \multirow{4}{*}{ A027 } & $0-30$ & 7.2 & 56.0 & 8.2 & 0.61 & 55.39 \\
\hline & $30-60$ & 7.6 & 42.0 & 8.1 & 0.54 & 41.46 \\
\hline & $60-90$ & 7.6 & 42.0 & 7.9 & 0.4 & 41.6 \\
\hline & $90-120$ & 8.0 & 15.4 & 8.3 & 0.53 & 14.87 \\
\hline
\end{tabular}

\section{Way Forward for Future Management}

\subsection{Short Term}

Recommendations should be based on thorough investigations to reclaim salt-affected soils, curtail the future expansion of soil salinity in the newly developed irrigated areas, and ensure successful utilization of salt-affected soils. Under the prevailing conditions of 
Ethiopia, a combination of different methods may be needed to control and/or minimize salinity and sodicity problems. Nonetheless, it should be noted that the practice may not always be successful because the suggested methods are based on the results of studies and investigations made in other areas. Therefore, necessary modifications might be required for local conditions.

Desalinization and de-alkalization of soils require proper land drainage, the introduction of improved cultural practices such as minimum tillage to avoid soil compaction, surface mulching; organic matter and crop residue management, use of good quality irrigation water, ensuring pre- and post-planting leaching to remove accumulated salts from the root zone, selection of proper seeding/planting methods, and avoiding cultivation of lands with a high groundwater table.

The measures are also needed to reduce the antagonistic effects of salinity and alkalinity and use of approved biological and agronomic reclamation particles. The reclamation of sodium-dominated soils through chemical amendments such as gypsum $\left(\mathrm{CaSO}_{4} \cdot 2 \mathrm{H}_{2} \mathrm{O}\right)$ is also needed. Generally, appropriate agricultural water management and agronomic practices that enforce strict and practical rules and regulations regarding the use of salt-affected soils and the expansion of the same need to be introduced. Monitoring, evaluating, and regulating the establishment and development of irrigated command areas in many parts of the country, especially in dry lowland areas, is needed.

\subsection{Long-Term, Future Research Directions}

Reclamation of saline and sodic soils, halting future expansion, and proper soil and water management require a profound knowledge of conservation and optimal utilization of natural resources. The main problems of soil reclamation and management in dry lowland areas are lack of locally amenable technologies and scientific knowledge. Hence, research has a vital and pivotal role in generating science and technology that will change the lives and livelihoods of millions of people on planet Earth. Research in Ethiopia should focus on developing appropriate science and technologies to control the salinity and sodicity of soils and halt future expansion of these problems. There is a need to state the problems of salt-affected soils correctly and advise the government on issues related to national policy and strategy to develop agriculture and seek lasting solutions to the emerging problem of Ethiopian agriculture; researchers have overwhelming responsibility.

Hence, the following are recommended for future research endeavors about managing saline and sodic soils: to investigate physical, mineralogy or colloids, chemistry, biology, and other environmental, economic, and social factors affecting soil salinity and sodicity be made and their relationships; to predict damages that may be caused due to increasing problems of salinity and sodicity; to create awareness on the processes of salinization and alkalization among farmers and develop preparedness plans to combat these problems. Investigation of the original sources of the salt-constituents in the salt-affected soils and irrigation water resources in the country is needed. We need to distinguish and classify saltaffected soils into different types and classes based on the results obtained from field visits and laboratory studies. We need to map salt-affected soils at zonal, regional, and national levels based on reconnaissance and a large-scale survey of irrigated and dryland soils. We must revise and popularize readily available technologies and facilitate the transfer of these technologies to the end-users. We must develop agricultural water management manuals and bulletins for use as guides for better water management practices. The impact on the environment and socioeconomic conditions must be assessed to establish a system to sustain agricultural production and protect the environment.

\section{Summary}

Soluble salt and sodium content in the soils of the rift valley and lowland irrigated areas of Ethiopia may harm crop production. Lowland irrigated areas are more vulnerable to soil salinity due to inappropriate agricultural water management and poor-quality water for irrigation. In particular, the soils with high sodium content and low soluble salt affect 
the physicochemical properties of the soils, resulting in lower water productivities. In addition to this, the accumulation of salts to the soil surface resulted in specific ions toxicity and nutritional imbalances, which minimizes or maximizes solubility and availabilities of critical nutrients; this made it responsible for low productivity. Moreover, the accumulation of soluble salts in the soil profile curtails crop growth by increasing the osmotic potential of the soil solution. Generally, the antagonistic effects of extreme concentrations of soluble salts limit plant growth and affect soil properties. Mainly, this problem poses tremendous challenges on crop production, particularly in the country's rift valley and lowland irrigated agriculture. However, decreased agricultural production and productivity resulted in unstable livelihood security, low economic returns, and poor quality of life.

Sustainable soil and irrigation water management practices have a vital role in enhancing crop production and soil productivity of lowland irrigated lands of the country. Many approaches are available to rehabilitate salt-affected soils. These include physical methods (irrigation and drainage management); chemical amendments (gypsum, $\mathrm{H}_{2} \mathrm{SO}_{4}$, combined application gypsum with other organic amendments); and biological approaches (screening salt-tolerant genotype, grow ameliorating crop species, crop species in rotation, etc.). The agro-ecological conditions in Ethiopia are comparable to many other countries where these approaches have successfully been tested. Therefore, there is a good potential for adopting these practices that will increase economic benefits to farmers.

Author Contributions: A.W.D. conceived the idea, collected, and analyzed the data, and drafted the paper. A.S.Q. helped in refining the concept, analysis of the data, and finalization of the draft article. All authors have read and agreed to the published version of the manuscript.

Funding: This research was funded by the International Fund for Agricultural Development (IFAD) (Grant No. 2000001100).

Data Availability Statement: Not applicable.

Conflicts of Interest: The authors declare no conflict of interest.

\section{References}

1. FAO. Status of the World's Soil Resources (SWSR)-Main Report; Food and Agriculture Organization of the United Nations and Intergovernmental Technical Panel on Soils: Rome, Italy, 2015; 650p.

2. Mustafa, M.A. Desertification Processes; UNESCO Chair of Desertification/University of Khartoum: Khartoum, Sudan, 2007.

3. Levy, G.J.; Goldstein, D.; Mamedov, A.I. Saturated Hydraulic Conductivity of Semiarid Soils: Combined Effects of Salinity, Sodicity, and Rate of Wetting. Soil Sci. Soc. Am. J. 2005, 69, 653-662. [CrossRef]

4. Sileshi, A.A.; Kibebew, K. Status of Salt Affected Soils, Irrigation Water Quality and Land suitability of Dubti/Tendaho Area, Northeastern Ethiopia. Doctoral Thesis, Haramaya University, Haramaya, Ethiopia, 2016.

5. Qureshi, A.S.; Tesfaye, E.M.; Melese, M.G. Extent Characterization and Management Strategies for the Salt Affected Soils in Ethiopia; Project Report, No. 2; Dubai, United Arab Emirates, 2020; p. 94. Available online: https://www.researchgate.net/publication/34 0362011_EXTENT_CHARACTERIZATION_AND_MANAGEMENT_STRATEGIES_FOR_THE_SALT-AFFECTED_SOILS_IN_ ETHIOPIA? channel=doi\&linkId=5e84cf8ca6fdcca789e641b0\&showFulltext=true (accessed on 6 December 2021).

6. Abrol, I.P.; Yadav, J.S.P.; Massoud, F.I. Soil Resources, Management and Conservation Service. In Salt-Affected Soils and Their Management; FAO: Rome, Italy, 1988; Volume 5, p. 14.

7. Halcrow, W. Water management manual. Amibara irrigation project. In Water Resource Development in Ethiopia; Forum for Social Studies: Addis Ababa, Ethiopia, 1983.

8. Chatterjee, A.; Geaumont, B.; DeSutter, T.; Hopkins, D.G.; Rakkar, M. Rapid shifts in soil organic carbon mineralization within sodic landscapes. Arid L. Res. Manag. 2015, 29, 255-263. [CrossRef]

9. Rengasamy, P. World salinization with emphasis on Australia. J. Exp. Bot. 2006, 57, 1017-1023. [CrossRef] [PubMed]

10. Brady, N.C.; Weil, R.R.; Weil, R.R. The Nature and Properties of Soils; Prentice Hall: Upper Saddle River, NJ, USA, 2008 ; Volume 13.

11. Wondim, G.B.; Daba, A.W.; Qureshi, A.S. Effects of Salinity on Producers' Livelihoods and Socio-economic Conditions; the Case of Afar Region, Northeastern Ethiopia. J. Sustain. Agric. Sci. 2020, 46, 35-46. [CrossRef]

12. Abebe, F.; Alamirew, T.; Abegaz, F. Appraisal and mapping of soil salinity problem in amibara irrigation Farms, middle awash basin, Ethiopia. Int. J. Innov. Sci. Res. 2015, 13, 298-314.

13. Mandal, S.; Raju, R.; Kumar, A.; Kumar, P.; Sharma, P.C. Current status of research, technology response and policy needs of salt-affected soils in India-A review. J. Indian Soc. Coast. Agric. Res 2018, 36, 40-53. 
14. Franceschini, F.; Signorini, R. Seawater intrusion via surface water vs. deep shoreline salt-wedge: A case history from the Pisa coastal plain (Italy). Groundw. Sustain. Dev. 2016, 2, 73-84. [CrossRef]

15. Ondrasek, G.; Rengel, Z. Environmental salinisation processes: Detection, implications \& solutions. Sci. Total Environ. 2020, 754, 142432.

16. Biggs, A.J.W.; Watling, K.M.; Cupples, N.; Minehan, K. Salinity risk assessment for the Queensland Murray-Darling Region. Queensl. Dep. Environ. Resour. Manag. Toowoomba 2010, 3, 125.

17. Gebrekidan, H. Investigation on Salt Affected Soils and Irrigation Water Quality in Melka Sedi-Amibara Plain, Rift Valley Zone of Ethiopia. Master's Thesis, Addis Ababa University, Addis Ababa, Ethiop, 1985; 132p.

18. Gebrekidan, H. Problems and Prospects of Salt Affected Soils in Ethiopia (Summary Literature Survey Report); AUA, Department of Plant Science: Iera Odos, Greece, 1987; 17p.

19. Gebrekidan, H. Evaluation of the Potential Use of Langbeinite (K2SO4. 2MgSO4) as a Reclaiming Material for Sodic and Saline Sodic Soils. Ph.D. Thesis, The University of Arizona, Tucson, AZ, USA, 1995.

20. Gebrekidan, H.; Mishra, B.B. Salt Affected Soils of Middle Awash River Basin of Ethiopia: Appraisal, Characterization and Classification. Geoderma 2005, 15, 7-15.

21. Shahid, S.A.; Abdelfattah, M.A.; Omar, S.A.S.; Harahsheh, H.; Othman, Y.; Mahmoudi, H. Mapping and Monitoring of Soil Salinization Remote Sensing, GIS, Modeling, Electromagnetic Induction and Conventional Methods-Case Studies. In Proceedings of the International Conference on Soils and Groundwater Salinization in Arid Countries, Muscat, Oman, 11-14 January 2010; Volume 59, p. 97.

22. Richards, L.A. Diagnosis and Improvement of Saline and Alkali Soils; US Department of Agriculture: Washington, DC, USA, 1954.

23. Gharaibeh, M.A.; Eltaif, N.I.; Albalasmeh, A.A. Reclamation of highly calcareous saline sodic soil using Atriplex halimus and by-product gypsum. Int. J. Phytoremediation 2011, 13, 873-883. [CrossRef]

24. Zaman, M.; Shahid, S.A.; Heng, L. Guideline for Salinity Assessment, Mitigation and Adaptation Using Nuclear and Related Techniques; Springer Nature: Basingstoke, UK, 2018; ISBN 331996190X.

25. Gupta, M.; Srivastava, P.K.; Niranjan, A.; Tewari, S.K. Use of a bioaugmented organic soil amendment in combination with gypsum for Withania somnifera growth on sodic soil. Pedosphere 2016, 26, 299-309. [CrossRef]

26. Mishra, V.K.; Jha, S.K.; Damodaran, T.; Singh, Y.P.; Srivastava, S.; Sharma, D.K.; Prasad, J. Feasibility of coal combustion fly ash alone and in combination with gypsum and green manure for reclamation of degraded sodic soils of the Indo-Gangetic Plains: A mechanism evaluation. L. Degrad. Dev. 2019, 30, 1300-1312. [CrossRef]

27. Worku, A.; Bedadi, B. Studies on soil physical properties of salt affected soil in Amibara area, central rift valley of Ethiopia. Int. J. Agric. Sci. Nat. Resour. 2016, 3, 8-17.

28. Asfaw, K.G.; Itanna, F. Screening some tef [Eragrostis tef (Zucc.) Trotter] accessions/varieties for salt tolerance during germination and seedling stage. Momona Ethiop. J. Sci. 2009, 1, 17-29. [CrossRef]

29. Tsegaye, G. Surface Water-Groundwater Interactions and Effects of Irrigation on Water and Soil Resources in the Awash Valley; AAU Institutional Repository: Addis Ababa, Ethiopia, 2009.

30. Mohammed, H.; Mishra, B.B. Soils of Jijiga and Gode Research Centers; AAU Institutional Repository: Addis Ababa, Ethiopia, 2005.

31. Mesfin, A. Irrigation for Sustainable Agricultural Development in Ethiopia, Ethiop. J. Agric. Sci. 2015, 25, 31-44.

32. Mintesinot, D. Salt Affected Soils in Dire Dawa, Ethiopia. A Characterization and Classification MSc; Haramaya University: Haramaya, Ethiopia, 2020.

33. Ganjegunte, G.K.; Sheng, Z.; Clark, J.A. Soil salinity and sodicity appraisal by electromagnetic induction in soils irrigated to grow cotton. L. Degrad. Dev. 2014, 25, 228-235. [CrossRef]

34. Nekir, B. Effect of Organic Matter on Rice Nitrogen and Phosphorus Use Efficiency Under Calcareous Sodic Soil of Amibara District, Ethiopia. J. Agric. Crop. 2019, 5, 178-185. [CrossRef]

35. Beakal, T.; Hussein, M.; Alemayehu, A. The effect of salinity on germination, vegetative and final growth stage of different rice (Oryza sativa L.) genotypes. J. Anim. Plant Sci. 2016, 29, 4651-4664.

36. Fageria, N.K.; Gheyi, H.R.; Moreira, A. Nutrient bioavailability in salt affected soils. J. Plant Nutr. 2011, 34, 945-962. [CrossRef]

37. Fallovo, C.; Rouphael, Y.; Rea, E.; Battistelli, A.; Colla, G. Nutrient solution concentration and growing season affect yield and quality of Lactuca sativa L. var. acephala in floating raft culture. J. Sci. Food Agric. 2009, 89, 1682-1689. [CrossRef]

38. Chinnusamy, V.; Jagendorf, A.; Zhu, J. Understanding and improving salt tolerance in plants. Crop Sci. 2005, 45, 437-448. [CrossRef]

39. Qureshi, A.S.; Daba, A.W. Differential analysis of five quinoa (Chenopodium quinoa W.) genotypes under different salt stresses in a controlled environment. Am. J. Sustain. Agric. 2019, 13, 1-17.

40. Gelaye, K.K.; Zehetner, F.; Loiskandl, W.; Klik, A. Comparison of growth of annual crops used for salinity bioremediation in the semi-arid irrigation area. Plant Soil Environ. 2019, 65, 165-171. [CrossRef]

41. Kitila, K.; Chala, A.; Workina, M. Effect of Gypsum and compost Application in Reclaiming Sodic soils at Small Scale Irrigation Farm in Bora District of East Shewa Zone, Oromia, Ethiopia. Agriways 2020, 8, 28-44. [CrossRef]

42. Daba, A.W.; Qureshi, A.S.; Nisaren, B.N. Evaluation of some rhodes grass (Chloris gayana) genotypes for their salt tolerance, biomass yield and nutrient composition. Appl. Sci. 2019, 9, 143. [CrossRef]

43. Farifteh, J.; Farshad, A.; George, R.J. Assessing salt-affected soils using remote sensing, solute modelling, and geophysics. Geoderma 2006, 130, 191-206. [CrossRef] 
44. Shirale, A.O.; Kharche, V.K.; Wakode, R.R.; Meena, B.P.; Das, H.; Gore, R.P. Influence of gypsum and organic amendments on soil properties and crop productivity in degraded black soils of Central India. Commun. Soil Sci. Plant Anal. 2018, 49, $2418-2428$. [CrossRef]

45. Setia, R.; Marschner, P.; Baldock, J.; Chittleborough, D. Is $\mathrm{CO}_{2}$ evolution in saline soils affected by an osmotic effect and calcium carbonate? Biol. Fertil. Soils 2010, 46, 781-792. [CrossRef]

46. Setia, R.; Smith, P.; Marschner, P.; Gottschalk, P.; Baldock, J.; Verma, V.; Setia, D.; Smith, J. Simulation of salinity effects on past, present, and future soil organic carbon stocks. Environ. Sci. Technol. 2012, 46, 1624-1631. [CrossRef]

47. Kumar, S.; Raju, R.; Sheoran, P.; Sharma, R.; Yadav, R.K.; Singh, R.K.; Sharma, P.C.; Chahal, V.P. Techno-economic evaluation of recharge structure as localized drainage option for sustainable crop production in sodic agro-ecosystems. Indian J. Agric. Sci. 2020, 90, 212-219.

48. Machado, R.M.A.; Serralheiro, R.P. Soil salinity: Effect on vegetable crop growth. Management practices to prevent and mitigate soil salinization. Horticulturae 2017, 3, 30. [CrossRef]

49. Ayenew, T. Water management problems in the Ethiopian rift: Challenges for development. J. Afr. Earth Sci. 2007, 48, 222-236. [CrossRef]

50. Qadir, M.; Quillérou, E.; Nangia, V.; Murtaza, G.; Singh, M.; Thomas, R.J.; Drechsel, P.; Noble, A.D. Economics of salt-induced land degradation and restoration. Nat. Resour. Forum 2014, 38, 282-295. [CrossRef]

51. Qureshi, A.S.; Mohammed, M.; Daba, A.W.; Hailu, B.; Belay, G.; Tesfaye, A.; Ertebo, T. Improving agricultural productivity on salt-affected soils in Ethiopia: Farmers' perceptions and proposals. Afr. J. Agric. Res. 2019, 14, 897-906.

52. Worku, A.; Mamo, B.N.L.; Bekele, T. Evaluation of some selected forage grasses for their salt tolerance, ameliorative effect and biomass yield under salt affected soil at Southern Afar, Ethiopia. J. Soil Sci. Environ. Manag. 2019, 10, 94-102.

53. Bekele, T.; Worku, A.; Mamo, L.; Nekir, B.; Aregahegn, Z. Effect of Chemical Amendments and Nitrogen Fertilizer on Rice Yeild under Salt Affected Sodic Condition. Results Nat. Resour. Manag. Res. 2020, 7, 27-35.

54. Abate, S.; Belayneh, M.; Ahmed, F. Reclamation and amelioration of saline-sodic soil using gypsum and halophytic grasses: Case of Golina-Addisalem irrigation scheme, Raya Kobo Valley, Ethiopia. Cogent Food Agric. 2021, 7, 1859847. [CrossRef]

55. Mukhopadhyay, R.; Sarkar, B.; Jat, H.S.; Sharma, P.C.; Bolan, N.S. Soil salinity under climate change: Challenges for sustainable agriculture and food security. J. Environ. Manag. 2020, 280, 111736. [CrossRef]

56. Sudi, A.; Melese, M.; Heluf, G.K. Impact of Gypsum and Sulfuric Acid Application on Cotton Yield under Saline Sodic Soil Condition in Melka Sadi Irrigated Farm. Acad. J. Agric. Res. 2016, 4, 91-95.

57. Abegaz, F. Effect of sub-surface drainage system on groundwater table, soil salinity and crop yield in Melka Sadi pilot drainage scheme. In Proceedings of the 1st and Inaugural Conference of the Agronomy and Crop Physiology society of Ethiopia, Addis Ababa, Ethiopia, 30-31 May 1995; pp. 139-148.

58. Bekele, T.; Lemma, W.; Solomon, T. Effect of Gypsum and Farmyard Manure on Selected Physicochemical Properties of Saline Sodic soil, at Amibara, Ethiopia. Int. J. Nov. Res. Life Sci. 2019, 7, 15-26.

59. Yazdanpanah, N.; Pazira, E.; Neshat, A.; Mahmoodabadi, M.; Sinobas, L.R. Reclamation of calcareous saline sodic soil with different amendments (II): Impact on nitrogen, phosphorous and potassium redistribution and on microbial respiration. Agric. Water Manag. 2013, 120, 39-45. [CrossRef]

60. Zhu, F.; Huang, N.; Xue, S.; Hartley, W.; Li, Y.; Zou, Q. Effects of binding materials on microaggregate size distribution in bauxite residues. Environ. Sci. Pollut. Res. 2016, 23, 23867-23875. [CrossRef] [PubMed]

61. Bekele, T.; Nekir, B.; Mamo, L.; Worku, A. Effect of sole and combined application of biochar and gypsum on wheat productivity under saline sodic and sodic soil condition. Int. J. Nov. Res. Life Sci. 2021, 8, 1-9.

62. Dahlawi, S.; Naeem, A.; Rengel, Z.; Naidu, R. Biochar application for the remediation of salt-affected soils: Challenges and opportunities. Sci. Total Environ. 2018, 625, 320-335.

63. Murtaza, G.; Murtaza, B.; Usman, H.M.; Ghafoor, A. Amelioration of Saline-sodic Soil using Gypsum and Low Quality Water in Following Sorghum-berseem Crop Rotation. Int. J. Agric. Biol. 2013, 15, 640-648.

64. Nekir, B.; Mamo, L.; Worku, A.; Bekele, T. Evaluation of wheat varieties/lines for salt tolerance at different growth stages. Greener J. Soil Sci. Plant Nutr. 2019, 6, 1-7.

65. Macci, C.; Doni, S.; Peruzzi, E.; Mennone, C.; Masciandaro, G. Biostimulation of soil microbial activity through organic fertilizer and almond tree association. L. Degrad. Dev. 2016, 27, 335-345. [CrossRef]

66. Wani, S.H.; Kumar, V.; Shriram, V.; Sah, S.K. Phytohormones and their metabolic engineering for abiotic stress tolerance in crop plants. Crop J. 2016, 4, 162-176. [CrossRef]

67. Mamo, L.; Bekele, T.; Nekir, B.; Worku, A. Screening of Different Sesame (Sesamum indicum L.) Accessions for Salt Tolerance at Different Growth Stages. Int. J. Nov. Res. Life Sci. 2021, 8, 21-27.

68. Hailu, B.; Mehari, H.; Tamiru, H. Evaluation of Sorghum for Salt Stress Tolerance Using Different Stages as Screening Tool in Raya Valley, Northern Ethiopia. Ethiop. J. Agric. Sci. 2020, 30, 265-276.

69. Mamo, L.; Nekir, B.; Bekele, T.; Worku, A. Evaluation of Wheat (Triticum aestivum L.) Accession for Salt Tolerance at Different Growth Stages. Results Nat. Resour. Manag. Res. 2020, 7, 44-54. 
70. Hailu, B.; Mehari, H.; Tesfay, A. Screening of Some Selected Tef Varieties/Lines for their Salt Stress Tolerance. J. Nat. Sci. Res. 2019, 9. [CrossRef]

71. Halcrow, S.I.R.W. Melka Sadi Pilot Drainage Scheme Final Report. 1986. Available online: http://197.156.72.153:8080/xmlui/handle/ 123456789/1364 (accessed on 6 December 2021). 